\title{
Fed-Batch Production of Saccharomyces cerevisiae L-Asparaginase II by Recombinant Pichia pastoris MUT $^{s}$ Strain
}

\section{OPEN ACCESS}

Edited by:

Saurabh Dhiman,

South Dakota School of Mines and Technology, United States

Reviewed by:

Valeria De Carvalho Santos-Ebinuma,

São Paulo State University, Brazil Kentaro Inokuma

Kobe University, Japan

*Correspondence: André M. Lopes

amorenilopes@gmail.com

Adalberto Pessoa Jr. pessoajr@usp.br

tThese authors have contributed equally to this work

Specialty section:

This article was submitted to Bioprocess Engineering,

a section of the journal

Frontiers in Bioengineering and

Biotechnology

Received: 23 July 2018 Accepted: 22 January 2019

Published: 08 February 2019

Citation:

Rodrigues D, Pillaca-Pullo O, Torres-Obreque K, Flores-Santos J, Sánchez-Moguel I, Pimenta MV,

Basi T, Converti A, Lopes AM,

Monteiro G, Fonseca LP and

Pessoa A Jr (2019) Fed-Batch

Production of Saccharomyces cerevisiae L-Asparaginase II by

Recombinant Pichia pastoris MUTS

Strain.

Front. Bioeng. Biotechnol. 7:16. doi: 10.3389/fbioe.2019.00016
David Rodrigues ${ }^{1 \dagger}$, Omar Pillaca-Pullo ${ }^{2 \dagger}$, Karin Torres-Obreque ${ }^{2}$, Juan Flores-Santos ${ }^{2}$, Ignacio Sánchez-Moguel ${ }^{2}$, Marcela V. Pimenta ${ }^{2}$, Tajindar Basi ${ }^{3}$, Attilio Converti ${ }^{4}$, André M. Lopes ${ }^{5 *}$, Gisele Monteiro ${ }^{2}$, Luís P. Fonseca ${ }^{1}$ and Adalberto Pessoa Jr. ${ }^{2 \star}$

${ }^{1}$ Bioengineering Department of Instituto Superior Técnico, Institute of Bioengineering and Biosciences, Universidade de Lisboa, Lisbon, Portugal, ${ }^{2}$ Department of Pharmaceutical-Biochemical Technology, School of Pharmaceutical Sciences, University of São Paulo, São Paulo, Brazil, ${ }^{3}$ Department of Pharmacy, King's College London, London, United Kingdom, ${ }^{4}$ Department of Civil, Chemical and Environmental Engineering, Genova, Italy, ${ }^{5}$ Faculty of Pharmaceutical Sciences, University of Campinas, Campinas, Brazil

L-Asparaginase (ASNase) is used in the treatment of acute lymphoblastic leukemia, being produced and commercialized only from bacterial sources. Alternative Saccharomyces cerevisiae ASNase II coded by the ASP3 gene was biosynthesized by recombinant Pichia pastoris MUTS under the control of the AOX1 promoter, using different cultivation strategies. In particular, we applied multistage fed-batch cultivation divided in four distinct phases to produce ASNase II and determine the fermentation parameters, namely specific growth rate, biomass yield, and enzyme activity. Cultivation of recombinant $P$. pastoris under favorable conditions in a modified defined medium ensured a dry biomass concentration of $31 \mathrm{gdcw} \cdot \mathrm{L}^{-1}$ during glycerol batch phase, corresponding to a biomass yield of 0.77 gdcw. $g_{\text {glycerol }}^{-1}$ and a specific growth rate of $0.21 \mathrm{~h}^{-1}$. After $12 \mathrm{~h}$ of glycerol feeding under limiting conditions, cell concentration achieved 65 gdcw. $L^{-1}$ while ethanol concentration was very low. During the phase of methanol induction, biomass concentration achieved $91 \mathrm{gdcw}_{\mathrm{d}} \mathrm{L}^{-1}$, periplasmic specific enzyme activity $37.1 \mathrm{U} \cdot \mathrm{g}_{\mathrm{dcw}}^{-1}$, volumetric enzyme activity $3,315 \mathrm{U} \cdot \mathrm{L}^{-1}$, overall enzyme volumetric productivity $31 \mathrm{U} \cdot \mathrm{L}^{-1} \cdot \mathrm{h}^{-1}$, while the specific growth rate fell to $0.039 \mathrm{~h}^{-1}$. Our results showed that the best strategy employed for the ASNase II production was using glycerol fed-batch phase with pseudo exponential feeding plus induction with continuous methanol feeding.

Keywords: L-Asparaginase, Pichia pastoris, defined medium, fed-batch fermentation, high cell density culture, heterologous protein production

\section{INTRODUCTION}

L-Asparaginase or ASNase (EC 3.5.1.1, L-asparagine amidohydrolase) is the enzyme that catalyzes the conversion of L-asparagine to aspartic acid and ammonia. It is used as a fundamental drug in protocols for the treatment of acute lymphoblastic leukemia (ALL). Up to now, only bacterial enzymes either modified (PEGylated) from Escherichia coli or unmodified from E. coli and Erwinia chrysanthemi have been approved for ALL treatment (Ali et al., 2016; Lopes et al., 2017; Santos et al., 2017). Even with all the success achieved with bacterial ASNases, there are still adverse 
effects (Dunlop et al., 1978, 1980; Panosyan et al., 2004; Liu et al., 2016); therefore, there is a demand for new serologically different enzymes with improved characteristics such as less immunogenicity with similar or improved therapeutic effects (Narta et al., 2007). For this purpose, Saccharomyces cerevisiae ASNase II significantly differs in several aspects from the bacterial enzymes, showing higher stability, optimum $\mathrm{pH}$ close to physiologic human conditions and lower allergenic potential (Jones, 1977; Dunlop et al., 1978, 1980; Ferrara et al., 2006). Although $S$. cerevisiae is able to add posttranslational modification to proteins such as glycosylation, it causes hyperglycosylation that increases immunogenicity (Looser et al., 2015) and has lower secretory capacity compared to Pichia pastoris (Zhang et al., 2000a).

Pichia pastoris has been widely used for the expression of more than 1,000 heterologous proteins (Itzel et al., 2016). The success of this yeast as an expression system is related to its ability to reach high cell densities (Pichia Fermentation Process Guidelines, 2002) on simple, inexpensive and chemically-defined media as well as the use of simple techniques for its genetic manipulation (Cereghino and Cregg, 2000). Among the various advantages that make $P$. pastoris so attracting in heterologous protein production are protein processing and post-translational modification that allow for eukaryotic protein proper folding and activity (Itzel et al., 2016; Sun et al., 2016). In addition, this yeast has a well-developed secretory system, prefers respiratory growth, and produces little ethanol (Cereghino and Cregg, 2000).

At the transcriptional level, the carbon source plays an important role in regulating enzyme synthesis (Brierley et al., 1990), because catabolite repression is exerted by many compounds, especially glucose and ethanol (Meagher and Inan, 2001). Cultivation of recombinant $P$. pastoris expressing a product under the control of the highly regulated Alcohol Oxidase I ( $A O X 1)$ promoter in high cell density cultures is often carried out according to a multi-stage fermentation protocol (Zhang et al., 2006). Typically, this process is divided into two major stages: growth and induction/production (Brierley et al., 1990; Chiruvolu et al., 1998; Cereghino and Cregg, 2000; Pichia Fermentation Process Guidelines, 2002). In the growth stage, a large cell mass is obtained using glycerol as a carbon source, because $P$. pastoris grows significantly faster in this substrate than in methanol (Looser et al., 2015). This stage is divided in two phases: glycerol batch phase (GBP) and glycerol fed-batch phase (GFP). The recombinant protein induction and production take place during a methanol fed-batch phase (MFP) (Looser et al., 2015), which is essential to prevent either overfeeding or underfeeding of substrate to the culture medium (Dietzsch et al., 2011; Looser et al., 2015).

Based on this background, we investigated in this study the production of ASNase by a methylotrophic recombinant $P$. pastoris strain carrying the ASP3 gene that encodes for $S$. cerevisiae ASNase II. Different glycerol and methanol feeding strategies, which are known to play a key role on heterologous protein production by recombinant microorganisms, were investigated. The main aim of this study was to develop a protocol to achieve high cell density cultures and determine the kinetic fermentation parameters for further development of this process.

\section{MATERIALS AND METHODS}

\section{Microorganism, Gene Cloning, and Protein Expression}

The ASP3 gene lacking the periplasmic signaling sequence (amino acids 1-25) was first cloned into the $p E T 22 b$ vector (Novagen, San Diego, CA, USA) for C-terminal histidine tail insertion. This construct was used as template to amplify the insert ASP3_26-362 + his using the following primers: forward AGCGGGCCTAGGGAAGAGAAGAATTCTTC by inserting the restriction site $A v r I I$ and reverse AAGGAAAAAAGC GGCCGCGGATCTCAGTG by inserting the NotI site. This insert was then digested with the Avr II and Not I enzymes and cloned into the $P$ PIC9K vector (Invitrogen, Carlsbad, CA, USA) at these restriction sites. The constructs were confirmed by sequencing. The correct clone was linearized with the Sal I restriction enzyme and transformed into the $P$. pastoris strain KM71 (arg4 his4 AOX1::ARG4) (Invitrogen) by electroporation. Transformants were selected for geneticin resistance (G418 at concentrations increasing from 0.25 to $4 \mathrm{mg} / \mathrm{mL}$ ). The clone with resistance to $4 \mathrm{mg} / \mathrm{mL}$ had its genomic DNA extracted with PureLink ${ }^{\circledR}$ Genomic DNA Mini kit (Life Technologies, Carlsbad, CA, USA). Integration of the pPIC9K + ASP3_26-362 + his construct was confirmed by PCR using the primers flanking the insertion site in the genome at the AOX locus (forward GACTGGTTCCAATTGACAAGC and reverse GCA AATGGCATTCTGACATCC). For more details about the steps of plasmid construction, gene sequence, and vector diagram, please see the Supplementary Information section.

\section{Pichia pastoris Cell Line Preservation and Reactivation}

To produce a working cell bank, the yeast strain was reactivated in yeast peptone dextrose (YPD) agar under incubation for $24 \mathrm{~h}$ at $30^{\circ} \mathrm{C}$. The activated cells were transferred to a $250-\mathrm{mL}$ Erlenmeyer flask containing $100 \mathrm{~mL}$ of buffered glycerol complex medium (BMGY) [composition: 10 g.L $\mathrm{L}^{-1}$ yeast extract, 20 g.L $\mathrm{L}^{-1}$ peptone, $100 \mathrm{mM}$ potassium phosphate, $\mathrm{pH}$ 6.0, 3.4 g.L $\mathrm{L}^{-1}$ yeast nitrogen base medium, $10 \mathrm{~g} . \mathrm{L}^{-1}\left(\mathrm{NH}_{4}\right)_{2} \mathrm{SO}_{4}, 4 \mathrm{mg} . \mathrm{L}^{-1}$ biotin, and 10 g.L $\mathrm{L}^{-1}$ glycerol]. The culture was incubated in an orbital shaker (New Brunswick Scientific Excella ${ }^{\circledR}$ E24, Edison, NJ, USA) at $30^{\circ} \mathrm{C}$ and $250 \mathrm{rpm}$ until an optical density $>30$ was reached. Cells were then stored at $-80^{\circ} \mathrm{C}$ in BMGY enriched with $20 \%(\mathrm{v} / \mathrm{v})$ glycerol in $1.5-\mathrm{mL}$ microtubes. To prepare the pre-inoculum, cells were thawed and inoculated in a $250-\mathrm{mL}$ Erlenmeyer flask containing $50 \mathrm{~mL}$ of BMGY medium under the same conditions as above.

\section{Kinetic Parameters of Growth and Yield of Biomass}

Biomass specific growth rate $(\mu)$ was estimated from the experimental data of biomass concentration by the equation (Sabo et al., 2019):

$$
\mu=\frac{1}{\left(\mathrm{~T}_{\mathrm{f}-} \mathrm{T}_{\mathrm{i}}\right)} \ln \frac{\mathrm{X}_{\mathrm{f}}}{\mathrm{X}_{\mathrm{i}}}
$$


where $X_{f}$ and $X_{i}$ are the final and initial biomass concentrations, and $T_{f}$ and $T_{i}$ the mean final and initial times, respectively.

The yield of biomass $\left(\mathrm{Y}_{\mathrm{x} / \mathrm{s}}\right)$ on consumed substrate was defined as:

$$
Y_{\frac{x}{s}}=\frac{\left(X_{f}-X_{i}\right)}{\left(S_{f}-S_{i}\right)}
$$

where $S_{\mathrm{f}}$ and $S_{\mathrm{i}}$ are the final and initial glycerol concentrations, respectively.

\section{Cultures of Pichia pastoris in Shake Flasks}

Cultures were carried out using a previously-prepared preinoculum where the frozen suspension was reactivated. After inoculation with a dry cell weight $(\mathrm{dcw})$ concentration of about 1 $\mathrm{g}_{\mathrm{dcw}} \cdot \mathrm{L}^{-1}, 250-\mathrm{mL}$ Erlenmeyer flasks containing $50 \mathrm{~mL}$ of BMGY or of defined medium [modified basal salt medium (BSMm) or modified salt fermentation medium (SFMm)] were incubated as above until glycerol depletion. A $50-\mathrm{mL}$ aliquot of fermented broth was centrifuged at $3,320 \mathrm{~g}$ and $4^{\circ} \mathrm{C}$ for $10 \mathrm{~min}$ and resuspended in $250-\mathrm{mL}$ Erlenmeyer flasks containing $50 \mathrm{~mL}$ of buffered methanol complex medium (BMMY) having the same composition as BMGY except for $30 \mathrm{~mL} . \mathrm{L}^{-1}$ methanol instead of $10 \mathrm{~g} . \mathrm{L}^{-1}$ glycerol. The ASNase II induction phase was carried out at $20^{\circ} \mathrm{C}$ and $250 \mathrm{rpm}$ on the same medium as that used for the growth phase, by two pulse additions of $30 \mathrm{~mL} . \mathrm{L}^{-1}$ of pure methanol at the start and after $24 \mathrm{~h}$. The induction phase was ended after $48 \mathrm{~h}$.

BSMm contained 26.7 mL.L ${ }^{-1}$ of $85 \%$ (v/v) $\mathrm{H}_{3} \mathrm{PO}_{4}, 0.93$ g. $\mathrm{L}^{-1}$ $\mathrm{CaSO}_{4}, 18.2$ g.L $\mathrm{L}^{-1} \mathrm{~K}_{2} \mathrm{SO}_{4}, 14.9$ g.L ${ }^{-1} \mathrm{MgSO}_{4} 7 \mathrm{H}_{2} \mathrm{O}, 4.13$ g.L $\mathrm{L}^{-1}$ $\mathrm{KOH}, 13-20$ g.L ${ }^{-1}\left(\mathrm{NH}_{4}\right)_{2} \mathrm{SO}_{4}$, and $4.35 \mathrm{~mL} . \mathrm{L}^{-1}$ Pichia trace metal solution (PTM) (composition: 6.0 g. $\mathrm{L}^{-1} \mathrm{CuSO}_{4} 5 \mathrm{H}_{2} \mathrm{O}$, 0.088 g.L $\mathrm{L}^{-1} \mathrm{KI}, 3.0$ g.L ${ }^{-1} \mathrm{MnSO}_{4} \mathrm{H}_{2} \mathrm{O}, 0.2$ g.L $\mathrm{L}^{-1} \mathrm{Na}_{2} \mathrm{MoO}_{4}^{\cdot} 2 \mathrm{H}_{2} \mathrm{O}$, 0.02 g.L ${ }^{-1} \mathrm{H}_{3} \mathrm{BO}_{3}, 0.5$ g.L ${ }^{-1} \mathrm{CoCl}_{2}, 20.0$ g.L ${ }^{-1} \mathrm{ZnCl}_{2}, 65.0$ g.L ${ }^{-1}$ $\mathrm{FeSO}_{4} 7 \mathrm{H}_{2} \mathrm{O}$, 0.2 g.L $\mathrm{L}^{-1}$ biotin, $5.0 \mathrm{~mL} . \mathrm{L}^{-1}$ concentrated $\mathrm{H}_{2} \mathrm{SO}_{4}$, and $\mathrm{pH}$ adjusted to 5.0 with $\mathrm{NaOH}$ ), while SFMm contained 12 g.L $\mathrm{L}^{-1} \mathrm{KH}_{2} \mathrm{PO}_{4}, 4.7$ g.L $\mathrm{L}^{-1} \mathrm{MgSO}_{4} 7 \mathrm{H}_{2} \mathrm{O}, 0.36$ g.L $\mathrm{L}^{-1}$ $\mathrm{CaCl}_{2} 2 \mathrm{H}_{2} \mathrm{O}, 13-20$ g.L $\mathrm{L}^{-1}\left(\mathrm{NH}_{4}\right)_{2} \mathrm{SO}_{4}$, and $4.35 \mathrm{ml} . \mathrm{L}^{-1} \mathrm{PTM}$ ( $\mathrm{pH}$ adjusted to 5.0 with $\mathrm{NaOH}$ ).

\section{$3^{3-1}$ Fractional Factorial Design for the Induction Phase in Shake Flasks}

The induction phase was investigated through experiments carried out according to a Box-Behnken design (Box and Behnken, 1960; Wang et al., 2007; Luo, 2012) where temperature $\left(x_{1}\right)$, methanol concentration $\left(x_{2}\right)$ and induction time $\left(x_{3}\right)$ were selected as the independent variables, while periplasmic specific ASNase II activity $\left(\mathrm{U}_{\mathrm{g}} \mathrm{g}^{-1}\right)$ and biomass concentration $\left(\mathrm{g}_{\mathrm{dcw}} \cdot \mathrm{L}^{-1}\right)$ as the responses (Table 1). According to this design, each variable was varied at three levels, namely 15,20 , and $25^{\circ} \mathrm{C}$ for $x_{1}, 1,2$, and $3 \%(\mathrm{v} / \mathrm{v})$ for $x_{2}$, and 48,72 , and $96 \mathrm{~h}$ for $x_{3}$, giving a total of 11 runs including two repetitions of the central point to estimate the pure error. The results were analyzed by means of Statistica software, version 10 (StatSoft, Tulsa, OK, USA).

Cultures were carried out with about $1 \mathrm{~g}_{\mathrm{dcw}} \cdot \mathrm{L}^{-1}$ initial cell concentration in BMGY. After glycerol depletion, cells were harvested by centrifugation at $3,320 \mathrm{~g}$ for $10 \mathrm{~min}$ at room
TABLE 1 $\mid 3^{3-1}$ Fractional factorial design used to investigate $P$. pastoris cultures in shake flasks.

\begin{tabular}{lccccc}
\hline Run & $\begin{array}{c}\text { Methanol } \\
\text { concentration } \\
(\% \text { v/v) }\end{array}$ & $\begin{array}{c}\text { Temperature } \\
\left({ }^{\circ} \mathbf{C}\right)\end{array}$ & $\begin{array}{c}\text { Induction } \\
\text { time (h) }\end{array}$ & $\begin{array}{c}\text { Periplasmic } \\
\text { ASNase II } \\
\text { activity } \\
\left(\mathbf{U . g} \mathbf{g}^{-1}\right)\end{array}$ & $\begin{array}{c}\text { Biomass } \\
\text { concentration } \\
\left(\mathbf{g}_{\mathbf{d c w}} \cdot \mathbf{L}^{-1} \mathbf{)}\right.\end{array}$ \\
\hline 1 & 1.0 & 15 & 48 & 7.9 & 17.0 \\
2 & 1.0 & 20 & 96 & 12.8 & 21.0 \\
3 & 1.0 & 25 & 72 & 5.4 & 15.7 \\
4 & 2.0 & 15 & 96 & 9.3 & 26.3 \\
$5^{\mathrm{a}}$ & 2.0 & 20 & 72 & 12.9 & 23.9 \\
$6^{\mathrm{a}}$ & 2.0 & 20 & 72 & 13.1 & 23.2 \\
$7^{\mathrm{a}}$ & 2.0 & 20 & 72 & 12.7 & 24.2 \\
8 & 2.0 & 25 & 48 & 7.1 & 20.7 \\
9 & 3.0 & 15 & 72 & 5.1 & 31.1 \\
10 & 3.0 & 20 & 48 & 16.2 & 18.1 \\
11 & 3.0 & 25 & 96 & 7.8 & 22.0 \\
\hline
\end{tabular}

Independent variables: methanol concentration, temperature, and induction time; Responses: periplasmic specific ASNase II activity and biomass concentration. ${ }^{\text {a }}$ Repetition of central point.

temperature, and the supernatant was discarded. After washing with $100 \mathrm{mM}$ phosphate buffer, $\mathrm{pH} 6.0$, the cell pellet was suspended in $50 \mathrm{~mL}$ of BMMY. The induction was performed under the conditions set by the experimental design (Table 1).

\section{Pichia pastoris Cultivation in Bioreactor}

The inoculum was prepared by growing a stock culture of recombinant $P$. pastoris from $1.0 \mathrm{~mL}$ of unfrozen cell suspension in a $250-\mathrm{mL}$ Erlenmeyer flask containing $50 \mathrm{~mL}$ of BMGY medium, at $30^{\circ} \mathrm{C}$ and $250 \mathrm{rpm}$ in shaker incubator for $22 \mathrm{~h}$. After that, $5 \mathrm{~mL}$ of cell suspension were used to determine the dry cell weight $\left(\mathrm{g}_{\mathrm{dcw}}\right)$ by means of a moisture analyzer, model MOC63u unibloc (Shimadzu, Kyoto, Japan). The volume of cell suspension ensuring an initial biomass concentration of $1 \mathrm{~g}_{\mathrm{dcw}} \cdot \mathrm{L}^{-1}$ was centrifuged at 3,320 g, and the pellet resuspended in BSMm in a 3 L bioreactor, model Bioflo 115 (New Brunswick, Edison, NJ, USA).

Cultures were performed on BSMm plus 40 g. $\mathrm{L}^{-1}$ glycerol and 13 g. $\mathrm{L}^{-1}\left(\mathrm{NH}_{4}\right)_{2} \mathrm{SO}_{4}$. The bioreactor was operated at $30^{\circ} \mathrm{C}$ during cell growth and starvation phases, and $\mathrm{pH}$ was monitored and controlled automatically at 5.0 with $\mathrm{NaOH}$. During the induction phase, temperature was reduced at $20^{\circ} \mathrm{C}$, and medium $\mathrm{pH}$ was maintained at 6.0.

In general aspects, the experimental conditions proposed in sections Cultures of Pichia pastoris in Shake Flasks, $3^{3-1}$ Fractional Factorial Design for the Induction Phase in Shake Flasks, and Pichia pastoris Cultivation in Bioreactor were selected based on the work of Ferrara et al. (2006).

\section{Determination of Oxygen Mass Transfer Coefficient}

To evaluate the influence of oxygen mass transfer coefficient $\left(k_{\mathrm{L}} a\right)$ on cell growth and ethanol production, three different $k_{\mathrm{L}} a$ values, selected on previous screening of conditions (results not 
shown), were tested in bioreactor, namely $84 \mathrm{~h}^{-1}$ (1.0 vvm, 500 $\mathrm{rpm}) ; 115 \mathrm{~h}^{-1}$ (1.0 vvm, $\left.600 \mathrm{rpm}\right) ;$ and $160 \mathrm{~h}^{-1}$ (1.0 vvm, 700 $\mathrm{rpm})$, in batch mode until glycerol depletion.

$k_{\mathrm{L}} a$ was determined according to the gassing out method (Wise, 1951) by bubbling nitrogen into water $(2.0 \mathrm{~L})$ contained in the bioreactor to remove the dissolved oxygen, until the polarographic probe reached zero. $k_{\mathrm{L}} a$ values were estimated at $30^{\circ} \mathrm{C}$ as the slope of the straight line obtained plotting $\ln \left(1-C / C_{S}\right)$ vs. time (h) for different aeration rates and agitation conditions, being $C$ the dissolved oxygen concentration at time $t$ and $C_{S}$ that at saturation $\left(\mathrm{mg} \cdot \mathrm{L}^{-1}\right)$.

\section{Two Stage Fermentation}

The bioreactor was operated in batch mode for $20 \mathrm{~h}$ with an initial medium volume of $1.5 \mathrm{~L}$, after which fed-batch culture was performed with glycerol as carbon source for further biomass growth. During 50\% (w/v) glycerol fed-batch phase, the specific feeding flow rate was varied in the range 5.6-12.6 mL.L ${ }^{-1} \cdot \mathrm{h}^{-1}$ plus PTM solution at $15 \mathrm{~mL}$ PTM. $\mathrm{L}_{\text {glycerol solution }}^{-1}$ and $\left(\mathrm{NH}_{4}\right)_{2} \mathrm{SO}_{4}$ at $0.325 \mathrm{~g}_{(\mathrm{NH} 4) 2 \mathrm{SO} 4} \cdot \mathrm{g}_{\text {glycerol }}^{-1}$ for $12 \mathrm{~h}$. During both phases, the $\mathrm{pH}$ was maintained at 5.0 by $\mathrm{NaOH}$ addition, temperature at $30^{\circ} \mathrm{C}$, aeration at $1.0 \mathrm{vvm}$, and agitation at $700 \mathrm{rpm}$, corresponding to $k_{\mathrm{L}} a=160 \mathrm{~h}^{-1}$.

Glycerol volumetric consumption rate ( $r_{\text {glycerol }}$, $\mathrm{g}_{\text {glycerol }} \cdot \mathrm{L}^{-1} \cdot \mathrm{h}^{-1}$ ) was calculated from the bioreactor mass balance by the equation (Dietzsch et al., 2011; Körner, 2013):

$$
r_{\text {glycerol }}=\frac{\mu_{\text {set }}}{Y_{x / s}} \cdot X \cdot e^{\mu_{\text {set }} \cdot\left(t-t_{f}\right)}
$$

where $\mathrm{Y}_{\mathrm{x} / \mathrm{s}}$ is biomass yield $\left(\mathrm{g}_{\mathrm{dcw}} \cdot \mathrm{g}_{\mathrm{glycerol}}^{-1}\right), \quad X$ biomass concentration $\left(g_{\mathrm{dcw}} \cdot \mathrm{L}^{-1}\right), t$ the time $(\mathrm{h}), t_{f}$ the time when starting the feed (h), and $\mu_{\text {set }}$ the specific growth rate set for the fed-batch phase $\left(\mathrm{h}^{-1}\right)$ defined as in Equation (1).

To ensure an exponential feeding profile during the growth phase, the volumetric feeding rate $\left(F_{\mathrm{i}}, \mathrm{L} \cdot \mathrm{h}^{-1}\right)$ after the time interval $\Delta t(\mathrm{~h})$ was calculated as:

$$
F_{i}=\frac{V_{i}}{C_{\text {glycerol }}} r_{\text {glycerol, } \mathrm{i}}
$$

where:

$$
V_{i}=V_{i-1}+F_{i-1} \cdot \Delta t
$$

being $V_{\mathrm{i}}$ and $V_{\mathrm{i}-1}$ the volumes of medium in the bioreactor (L) after and before $\Delta t, C_{\text {glycerol }}$ the glycerol concentration in the feed solution (g. $\left.\mathrm{L}^{-1}\right), F_{\mathrm{i}-1}$ the volumetric feeding rate of glycerol solution before $\Delta t$, and $r_{\text {glycerol, }}$ the glycerol volumetric consumption rate after $\Delta t\left(\mathrm{~g}_{\mathrm{glycerol}} \cdot \mathrm{L}^{-1} \cdot \mathrm{h}^{-1}\right)$.

\section{Induction of L-Asparaginase Biosynthesis}

After a $1-2 \mathrm{~h}$ starvation period following the above high cell density culture, methanol fed-batch phase was performed feeding a $100 \%$ methanol solution at specific flow rates in the range $3.75-5.25 \mathrm{~mL} \cdot \mathrm{h}^{-1}$ plus $15 \mathrm{~mL}$ PTM. $\mathrm{L}_{\text {methanol }}^{-1}$ to induce ASNase II production. Different feeding regimes were tested, namely methanol addition by pulses up to 0.5 to $3 \%(\mathrm{v} / \mathrm{v})$ followed by dissolved oxygen spikes and pseudo-continuous methanol feeding. During the induction phase, temperature was maintained at $20^{\circ} \mathrm{C}$, aeration at $1.0 \mathrm{vvm}$, and agitation at 700 $\mathrm{rpm}$, corresponding to $k_{\mathrm{L}} a=160 \mathrm{~h}^{-1}$.

\section{Analytical Methods Biomass Quantification}

Biomass dry weight was quantified by measuring the optical density at $600 \mathrm{~nm}$ using a microplate reader, model Spectramax ${ }^{\circledR}$ plus 384 (Molecular Devices, Sunnyvale, CA, USA). The weight was measured again, and the dry weight was calculated as the difference between the final and initial values.

Cell concentration in the samples was then calculated according to the following standard curve of optical density at $600 \mathrm{~nm}\left(\mathrm{OD}_{600}\right)$ vs. dry cell weight concentration $(X)$, expressed in $\mathrm{g}_{\mathrm{dcw}} \cdot \mathrm{L}^{-1}$ :

$$
O D_{600}=1.8738 X-0.0211
$$

The standard curve was obtained using a series of dilutions of homogenous $P$. pastoris cell suspension cultivated in BMGY from unfrozen stock as previously described. Cells were centrifuged at $3,320 \mathrm{~g}$ for $25 \mathrm{~min}$ at room temperature, washed twice and resuspended in distillated water. Ten milliliter of this suspension were dried at $55^{\circ} \mathrm{C}$ in a $15-\mathrm{mL}$ pre-weighted dry Falcon tube until constant weight.

\section{Glycerol Quantification}

Glycerol concentration was determined by the Triglycerides Liquiform assay kit (Labtest Diagnostica, Lagoa Santa, MG, Brazil). Centrifuged samples $(10 \mu \mathrm{L})$ were mixed with $1.0 \mathrm{~mL}$ of triglycerides assay kit and incubated at $37^{\circ} \mathrm{C}$ for $10 \mathrm{~min}$. The optical density was read with the above microplate reader at $505 \mathrm{~nm}$ using distilled water as a blank. To prepare a standard curve, dilute solutions of pure glycerol (99.5\%, from Synth ${ }^{\circledR}$, São Paulo, Brazil) in the defined BSMm medium were used.

\section{Ethanol and Methanol Quantification}

Ethanol and methanol concentrations were determined by a gas chromatograph, model $6890 \mathrm{~N}$ (Agilent Technologies, Wilmington, DE, USA), equipped with a fused-silica capillary column Poraplot Q $(10 \mathrm{~m} \times 320 \mu \mathrm{m} \times 5 \mu \mathrm{m})$, and a split-splitless injector. The carrier gas was helium at a pressure of $60 \mathrm{kPa}$ in the injection port. The detector temperature was maintained at $280^{\circ} \mathrm{C}$. The gas flow rate was set at $0.8 \mathrm{~mL} \cdot \mathrm{min}^{-1}$, and $n$-propanol used as internal standard. Injections for desorption of standards from needle trap device were made by splitless mode for $3 \mathrm{~min}$ at injection port temperature of $280^{\circ} \mathrm{C}$, then the needle trap device was removed from the injector, and the system was switched into the split mode. The column oven temperature was held at $40^{\circ} \mathrm{C}$ for $5 \mathrm{~min}$, ramped to $150^{\circ} \mathrm{C}$ at the rate of $10^{\circ} \mathrm{C} \cdot \mathrm{min}^{-1}$ and held at the final temperature for $5 \mathrm{~min}$.

\section{ASNase Activity Measurement}

ASNase II activity was measured in whole cell suspension (periplasmic activity) based on asparagine hydroxylaminolysis, i.e., conversion of asparagine into $\beta$-aspartohydroxamate and 
ammonia. Samples $(1.0 \mathrm{~mL})$ of fermentation cultures were centrifuged at $3,320 \mathrm{~g}$ at $4^{\circ} \mathrm{C}$ for $10 \mathrm{~min}$, and cells were resuspended in $0.9 \mathrm{~mL}$ of $20 \mathrm{mM}$ Tris- $\mathrm{HCl}$ buffer ( $\mathrm{pH} 6.8), 0.2 \mathrm{~mL}$ of $100 \mathrm{mM}$ asparagine, and $0.2 \mathrm{~mL}$ of $1.0 \mathrm{M}$ hydroxylamine $(\mathrm{pH}$ 7.0) (Dunlop et al., 1978; de Castro Girão et al., 2016). After incubation at $37^{\circ} \mathrm{C}$ for $30 \mathrm{~min}, 0.5 \mathrm{~mL}$ of trichloroacetic acid (TCA) $/ \mathrm{FeCl}_{3}$ reagent $\left(50 \mathrm{~g} / \mathrm{L} \mathrm{TCA}\right.$ and $100 \mathrm{~g} / \mathrm{L} \mathrm{FeCl}_{3}$ in $0.66 \mathrm{M}$ $\mathrm{HCl}$ ) were added, and cell suspension centrifuged at 7,000 $\mathrm{g}$ for $10 \mathrm{~min}$. Supernatant optical density was read at $500 \mathrm{~nm}$ with the same equipment as above (Dunlop et al., 1980). Enzyme activity was measured by $\beta$-aspartohydroxamate formation through a calibration curve. One unit (U) of ASNase II activity was assumed to be the amount of enzyme able to release $1 \mu \mathrm{mol}$ of $\beta$ aspartohydroxamate per minute.

\section{Enzyme Identification by SDS-PAGE}

Samples of culture medium were assayed by SDS-PAGE in $12 \%$ polyacryamide gel $(1.5 \mathrm{~mm})$ to check the extracellular enzyme production and the purity degree (Sudhir et al., 2014). Protein bands were stained with Coomassie Brilliant Blue R-250 dye. Molecular mass bands were compared with those of Precision Plus Protein ${ }^{\mathrm{TM}}$ Standards (Bio RAD, Hercules, CA, USA).

\section{Protein Quantification}

Protein concentration in the culture medium was determined using the Bicinchoninic Acid (BCA) Protein Assay kit (SigmaAldrich, St. Louis, MO, USA). Briefly, the protein sample $(20 \mu \mathrm{L})$ was added to a 96 well plate containing $200 \mu \mathrm{L}$ of the prepared BCA working reagent solution and incubated for $30 \mathrm{~min}$ at $37^{\circ} \mathrm{C}$. Then, the optical density was read at $562 \mathrm{~nm}$. Total protein concentration was obtained by a standard curve of several dilutions of a 1,000 mg. $\mathrm{mL}^{-1}$ bovine serum albumin (BSA) stock solution.

\section{RESULTS AND DISCUSSION}

\section{ASNase Production in Shake Flasks on Complex Medium}

Heterologous protein expression in shake flask cultures of $P$. pastoris is usually performed in complex BMGY medium, whose composition, however, is not optimized; therefore, modifications have been proposed (Stratton et al., 1998; Pichia Fermentation Process Guidelines, 2002; Ghosalkar et al., 2008; Li et al., 2013). Even though $P$. pastoris can grow in a large range of $\mathrm{pH}$ (from 3.0 to 7.0) (Ahmad et al., 2014), our previous results (not shown) demonstrated that ASNase II activity did not significantly vary in the $\mathrm{pH}$ range 5.0-6.0. For this reason, the initial $\mathrm{pH}$ of the culture medium was adjusted to $\mathrm{pH} 6.0$ (Pichia Fermentation Process Guidelines, 2002; Ferrara et al., 2006) to avoid salt precipitation occurring at higher $\mathrm{pH}$ (Cos et al., 2006).

It is noteworthy that the experimental design shows how independent variables and interactions among them can influence the output responses. A lot of different factors are often taken into considerations such as culture medium components in combination with operating parameters (i.e., temperature, induction time, agitation intensity, and aeration rate, among others). However, in the presence of many factors, it is not advisable to adopt a complete design from the beginning, but it is rather preferable to start with a fractional design trying to identify the actually significant factors. Another advantage of using an experimental design is that it allows simultaneously studying more factors with fewer experiments compared with several parametric variations. Such a reduction of the set of experiments can be described mathematically as $3^{n-k}+2$, where $n$ is the number of factors to be investigated at the different levels (low, medium, and high) and $k$ is the number of steps to reduce the experimental design (Mandenius and Brundin, 2008). Some of the factors highlighted above can influence protein expression in $P$. pastoris, i.e., temperature, $\mathrm{MeOH}$ concentration, induction time, $\mathrm{pH}$, and medium composition (Jafari et al., 2011). For this reason, we employed a $3^{3-1}$ fractional factorial design to investigate the influence of methanol concentration, induction time and temperature on both periplasmic specific enzyme activity and biomass concentration in shake flasks (Table 1). Such a design, which is very useful to evaluate in a few experiments the simultaneous influence of independent variables on responses, is often used in bioprocess optimization (Mandenius and Brundin, 2008).

To describe the behavior of the system, second-order polynomial models were used to correlate independent variables with responses according to the equation:

$$
Y=\beta_{0}+\sum \beta_{i} x_{i}+\sum \beta_{i i} x_{i}^{2}+\sum \beta_{i j} x_{i} x_{j}
$$

where $Y$ is the response, $\beta_{0}$ is the interception coefficient, $\beta_{\mathrm{i}}$ are the linear terms, $\beta_{\mathrm{ii}}$ are the quadratic terms, $\beta_{\mathrm{ij}}$ are the interaction terms, and $x_{i}$ and $x_{j}$ are the coded levels of the independent variables.

Figure 1A, illustrates the Pareto chart of periplasmic specific ASNase II activity, in which the bar length is proportional to the standardized effect of the corresponding variable or interaction, and only bars beyond the vertical line correspond to statistically significant effects at 95\% confidence level $(p<0.05)$. It can be seen that the positive quadratic effect of temperature was by far the strongest one on this response, followed by the negative quadratic effect of induction time, while all the others were not statistically significant or very weak.

It is possible to observe in the response surface plot of Figure $1 \mathrm{C}$, that activity achieved maximum values at $20^{\circ} \mathrm{C}$ and gradually increased with methanol concentration. In contrast, Jafari et al. (2011) observed better anti-keratin 8 single-chain Fv TS1-218 production by $P$. pastoris $M U T^{s}$ using methanol concentration below $3 \%(\mathrm{v} / \mathrm{v})$ and lower temperatures $\left(10-20^{\circ} \mathrm{C}\right)$.

On the other hand, consistently with the observations of the Pareto chart, albeit only a few significant, the induction time exerted a negative effect on the expression level, therefore induction times as shorter as possible $(48 \mathrm{~h})$ should be used to maximize it (Figure 1B). Therefore, taking into account the simultaneous influence of the above factors, we selected as the most favorable conditions for maximum ASNase II expression (16.2 U.g ${ }^{-1}$ ) within the selected ranges of independent variables a temperature of $20^{\circ} \mathrm{C}$, a methanol concentration of $3 \%(\mathrm{v} / \mathrm{v})$ and an induction time of $48 \mathrm{~h}$. 

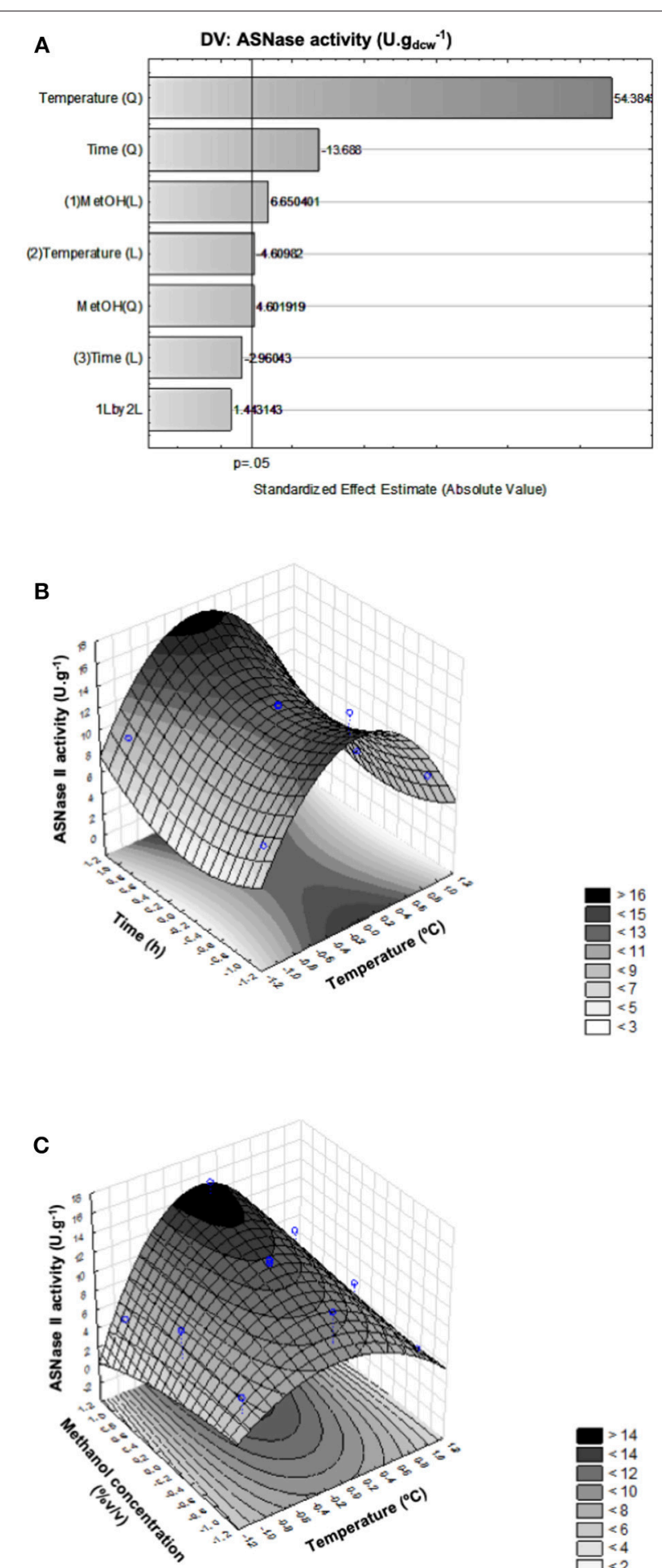

\section{ASNase Production in Shake Flasks on Defined Medium}

High cell density cultures of $P$. pastoris in bioreactor are usually carried out on chemically-defined high-salt concentration broth consisting of a modified basal salt medium (BSMm) enriched with a Pichia trace metal (PTM) solution (Ferrara et al., 2006; Julien, 2006; Ghosalkar et al., 2008; Li et al., 2013).

However, BSM has also some disadvantages, namely unbalanced composition, salt precipitation, and use of $\mathrm{NH}_{4} \mathrm{OH}$ as either nitrogen source or alkaline solution for $\mathrm{pH}$ control. $\mathrm{NH}_{4} \mathrm{OH}$ may be responsible for growth inhibition due to ammonia toxicity (Cos et al., 2006; Zhang et al., 2006; Ghosalkar et al., 2008; Santos et al., 2012). To face these constraints, $\mathrm{NH}_{4} \mathrm{OH}$ as nitrogen source was replaced by $\left(\mathrm{NH}_{4}\right)_{2} \mathrm{SO}_{4}$ at concentration in the range 13-20 g. $\mathrm{L}^{-1}$, and the $\mathrm{pH}$ controlled by addition of $\mathrm{NaOH}$ (D'Anjou and Daugulis, 2000; Cos et al., 2006; Ghosalkar et al., 2008).

Cell growth profiles in shake flasks using such BSMm and modified salt fermentation medium (SFMm) are shown in Figure 2A. In both culture media, $P$. pastoris grew similarly at the different $\mathrm{NH}_{4}^{+}$concentrations, demonstrating the absence of any $\mathrm{NH}_{4}^{+}$toxic effect within the tested concentration range. On the other hand, higher dry cell concentrations and cell yields were obtained in BSMm $\left(24.1 \pm 1.0 \mathrm{gdcw}_{\mathrm{dc}} \cdot \mathrm{L}^{-1}\right.$ and $0.60 \pm$ $\left.0.03 \mathrm{gdcw}_{\mathrm{dcw}} \cdot \mathrm{g}_{\text {glycerol }}^{-1}\right)$ compared with SFMm $\left(11.7 \pm 0.9 \mathrm{gdcw} \cdot \mathrm{L}^{-1}\right.$ and $0.29 \pm 0.02 \mathrm{~g}_{\mathrm{dcw}} \cdot \mathrm{g}_{\text {glycerol }}^{-1}$ ), while the $\mathrm{pH}$ decreased in both media from 5.0 to $<3.3$. These values in BSMm medium were close to those reported in literature after glycerol depletion in BSM in bioreactor (Zhang et al., 2000b; Hélène et al., 2001; Ghosalkar et al., 2008). In BSMm the stationary growth phase was delayed (around 22-24h) compared with SFMm (18h) and lasted almost the same time as in defined medium (Hélène et al., 2001; Ferrara et al., 2006). The better growth of P. pastoris in BSMm is confirmed by a specific growth rate that was on average $\left(0.153 \mathrm{~h}^{-1}\right)$ about $7 \%$ higher than that obtained in SFMm $(0.143$ $\mathrm{h}^{-1}$ ). Based on these considerations, the better production results obtained in the former medium suggested us to select it for bioreactor experiments.

There was no ASNase II activity at the end of the induction phase because of strong acidity $(\mathrm{pH} \leq 3.3)$ and low buffering capacity of both media. This result agrees with the observation that $S$. cerevisiae ASNase II periplasmic activity was fully inactivated at very low pH values (below 3.2) (Kim and Roon, 1983). As ASNase activity has an optimum pH of 7.0 (Dunlop and Roon, 1975; Ferrara et al., 2006), such acidic conditions were likely to alter its structure due to repulsion among positive charges, thereby distorting the catalytic site and reducing its activity. Since the lowest ammonium concentration (13 g.. $\left.\mathrm{L}^{-1}\right)$ gave similar results to the others, suggesting no nitrogen limitation, it was selected for subsequent runs to decrease reagent costs.

\section{Pichia pastoris Cultivation in Bioreactor}

To avoid a long oxygen limitation period in the bioreactor (Brierley et al., 1990; Chiruvolu et al., 1998), which would have led to ethanol accumulation (Brierley et al., 1990; Meagher and 


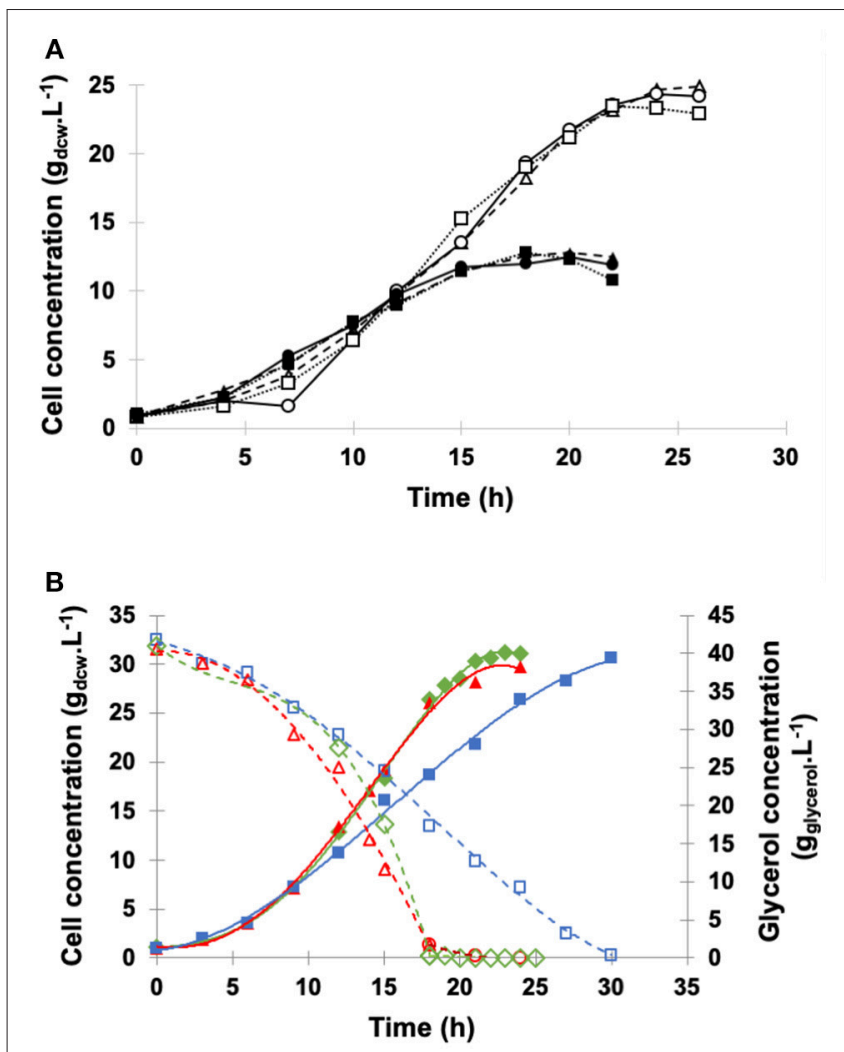

FIGURE 2 | Growth curves of $P$. pastoris. (A) Shake flask cultures carried out at $\mathrm{pH} 5.0,30^{\circ} \mathrm{C}$, agitation of $250 \mathrm{rpm}$, inoculum concentration of $1.0 \mathrm{~g} . \mathrm{L}^{-1} \mathrm{in}$ : ( $\Delta$ ) BSMm with $13 \mathrm{~g} \cdot \mathrm{L}^{-1}\left(\mathrm{NH}_{4}\right)_{2} \mathrm{SO}_{4}$; (o) $\mathrm{BSMm}$ with $15 \mathrm{~g} \cdot \mathrm{L}^{-1}\left(\mathrm{NH}_{4}\right)_{2} \mathrm{SO}_{4}$; ( $\square$ ) BSMm with $20 \mathrm{~g} \cdot \mathrm{L}^{-1}\left(\mathrm{NH}_{4}\right)_{2} \mathrm{SO}_{4} ;(\boldsymbol{\Delta}) \mathrm{SFMm}$ with $13 \mathrm{~g} \cdot \mathrm{L}^{-1}\left(\mathrm{NH}_{4}\right)_{2} \mathrm{SO}_{4}$; (•) SFMm with $15 \mathrm{~g} \cdot \mathrm{L}^{-1}\left(\mathrm{NH}_{4}\right)_{2} \mathrm{SO}_{4}$; (口) SFMm with $20 \mathrm{~g} \cdot \mathrm{L}^{-1}\left(\mathrm{NH}_{4}\right)_{2} \mathrm{SO}_{4}$. (B) Bioreactor fermentations carried out on BSMm. Dry cell concentration: $\left(\square k_{\mathrm{L}} a\right.$ $=84 \mathrm{~h}^{-1}$ (1.0 vvm, $\left.500 \mathrm{rpm}\right) ;(\mathbf{\Delta}) k_{\mathrm{L}} a=110 \mathrm{~h}^{-1}$ (1.0 vvm, $\left.600 \mathrm{rpm}\right) ;(\diamond) k_{\mathrm{L}} \mathrm{a}$ $=160 \mathrm{~h}^{-1}$ (1.0 vvm, $700 \mathrm{rpm}$ ). Glycerol concentration: $(\square) k_{\mathrm{L}} \mathrm{a}=84 \mathrm{~h}^{-1} ;(\triangle)$ $k_{\mathrm{L}} \mathrm{a}=110 \mathrm{~h}^{-1} ;(\diamond) k_{\mathrm{L}} \mathrm{a}=160 \mathrm{~h}^{-1}$. Other conditions: temperature $30^{\circ} \mathrm{C}$; inoculum concentration $1.0 \mathrm{gdcw}_{\mathrm{dc}} \mathrm{L}^{-1}$; $\mathrm{pH} 5.0$; broth volume $2.0 \mathrm{~L}$.

Inan, 2001; Looser et al., 2015) and consequent inhibition of recombinant protein induction, the growth phase on glycerol was divided in two stages, i.e., a glycerol batch phase (GBP) that allowed achieving a cell concentration $>25 \mathrm{~g}_{\mathrm{dcw}} \cdot \mathrm{L}^{-1}$ and a glycerol fed-batch phase (GFP) during which glycerol was fed in limiting level and cell density was $>50 \mathrm{~g}_{\mathrm{dcw}} \cdot \mathrm{L}^{-1}$. As a result, fermentations in bioreactor were carried out in three steps, namely GBP, GFP, and ASNase II production during methanol fed-batch phase (MFP), with only a short glycerol starvation period before starting MFP in BSMm.

\section{Selection of Aeration Conditions}

Taking into account that the aerobic growth of $P$. pastoris requires large amount of oxygen to ensure high cell density, to determine the best aeration and agitation conditions of GBP, three fermentations were carried out at $30^{\circ} \mathrm{C}$ in bioreactor on BSMm containing 13 g.L $\mathrm{L}^{-1}\left(\mathrm{NH}_{4}\right)_{2} \mathrm{SO}_{4}$ and 40 g.L $\mathrm{L}^{-1}$ glycerol under $k_{\mathrm{L}} a$ of 84,110 , and $160 \mathrm{~h}^{-1}$ and controlling the $\mathrm{pH}$ at 5.0 to favor salt solubility (Brierley et al., 1990; Pichia Fermentation
TABLE 2 | P. pastoris biomass yield $\left(Y_{\mathrm{X} / \mathrm{s}}\right)$, specific growth rate $(\mu)$ and cell productivity in 3.0-L bioreactor containing 2.0- $\mathrm{L}$ BSMm plus $\mathrm{PTM}$, at $30^{\circ} \mathrm{C}, \mathrm{pH}$ 5.0, initial glycerol concentration of $40 \mathrm{~g} . \mathrm{L}^{-1}$, and inoculum concentration of 1.0 $g_{d c w} \cdot L^{-1}$.

\begin{tabular}{lccc}
\hline $\boldsymbol{k}_{\mathrm{L}} \mathbf{a}\left(\mathbf{h}^{-\mathbf{1}}\right)$ & $\begin{array}{c}\mathbf{Y}_{\mathbf{x} / \mathbf{s}} \\
\left(\mathbf{g}_{\mathbf{d c w}} \cdot \mathbf{g}_{\text {glycerol }}^{-\mathbf{1}}\right)\end{array}$ & $\boldsymbol{\mu}\left(\mathbf{h}^{-1}\right)$ & $\begin{array}{c}\text { Cell productivity } \\
\left(\mathbf{g}_{\mathbf{d c w}} \cdot \mathbf{L}^{-\mathbf{1}} \cdot \mathbf{h}^{-\mathbf{1}}\right)\end{array}$ \\
\hline 84 & 0.73 & 0.11 & 0.51 \\
110 & 0.73 & 0.19 & 0.67 \\
160 & 0.77 & 0.21 & 0.71 \\
\hline
\end{tabular}

Process Guidelines, 2002; Ferrara et al., 2006). Figure 2B, shows the fermentation profiles until glycerol depletion.

Cell growth was very similar at $k_{\mathrm{L}} a$ of 110 and $160 \mathrm{~h}^{-1}$, achieving similar biomass yields $\left(\mathrm{Y}_{\mathrm{x} / \mathrm{s}}\right)\left(0.73\right.$ and $\left.0.77 \mathrm{~g} \cdot \mathrm{g}_{\text {glycerol }}^{-1}\right)$ and specific growth rates $(\mu)\left(0.19\right.$ and $\left.0.21 \mathrm{~h}^{-1}\right)$ (Table 2$)$, while at the lowest $k_{\mathrm{L}} a\left(84 \mathrm{~h}^{-1}\right)$, despite the almost coincident $\mathrm{Y}_{\mathrm{x} / \mathrm{s}}$ values, $\mu$ and cell productivity were $42-48 \%$ and $24-28 \%$ lower, respectively, due to reduction of the oxygen level. These $\mu$ values fall in the typical range for $P$. pastoris grown on glycerol as the sole carbon source (Körner, 2013; Ahmad et al., 2014; Looser et al., 2015) and are close to that reported for P. pastoris MUT employed to produce ASNase II (Ferrara et al., 2006).

The yields obtained in bioreactor were appreciably higher when compared to those obtained in shake flasks on the same medium (results not shown).

\section{Glycerol Feeding Profiles}

To achieve high cell densities, while simultaneously avoiding ethanol formation, GFP was carried out based on GBP growth and biomass yields. According to D'Anjou and Daugulis (2000), ethanol accumulation can in fact be avoided when $\mu<1 / 2 \mu_{\max }$.

A glycerol volumetric consumption rate of 2.6 $\mathrm{g}_{\text {glycerol }} \cdot \mathrm{L}^{-1} \cdot \mathrm{h}^{-1}$ was calculated for our system by Equation (3) at $k_{\mathrm{L}} a=160 \mathrm{~h}^{-1}$, being $\mu_{\text {set }}=0.072 \mathrm{~h}^{-1}$, and $\mathrm{Y}_{\mathrm{x} / \mathrm{s}}=$ $0.77 \mathrm{~g} . \mathrm{g}_{\text {glycerol }}^{-1}$ under these conditions. To modulate substrate consumption, we assumed that the maintenance coefficient $\left(m_{\mathrm{s}}\right)$ was $<<\mu$ during the exponential growth, $\mu$ and $\mathrm{Y}_{\mathrm{x} / \mathrm{s}}$ were constant, no oxygen limitation occurred during GFP, sampling volume, water evaporation and biomass dilution effect were negligible because of a volume variation $<10 \%$ (D'Anjou and Daugulis, 2000).

To avoid excess ammonium inhibition (Zhang et al., 2000a; Cos et al., 2006), a 50\% (w/v) glycerol solution containing 0.325

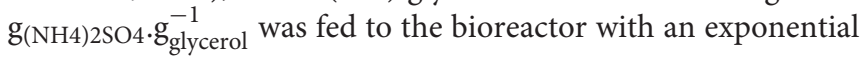
feeding profile (Equation 4). Exponential feeding was simulated by a pseudo-exponential feeding with step increases every $2 \mathrm{~h}$ alternated to constant feed $\left(13.1 \mathrm{~mL} \cdot \mathrm{h}^{-1}\right)$. Using the $\mu$ and $\mathrm{Y}_{\mathrm{x} / \mathrm{s}}$ values from batch fermentations and assuming a dry cell concentration of $28 \mathrm{~g} \mathrm{dcw} \cdot \mathrm{L}^{-1}$ and an initial volume of $1.5 \mathrm{~L}$, the flow rate pattern summarized in Table 3 was experimentally tested.

\section{High Cell Density Cultivations of Pichia pastoris}

To perform high cell density cultures, the feed rate was set so as to ensure substrate-limited growth in GFP and subsequent 
TABLE 3 | Values of the feed flow rate calculated by Equation (4) using $\mu=0.072$ $\mathrm{h}^{-1}, \mathrm{Y}_{\mathrm{x} / \mathrm{s}}=0.77 \mathrm{~g}_{\mathrm{dcw}} . \mathrm{g}_{\text {glycerol }}^{-1}$, initial cell concentration of $28 \mathrm{~g} . \mathrm{L}^{-1}$, and $50 \%$ (w/v) glycerol concentration, and tested in pseudo-exponential feeding runs.

\begin{tabular}{lc}
\hline Time (h) & Flow rate $\left(\mathbf{m L . h} \mathbf{~}^{-\mathbf{1}}\right)$ \\
\hline $0-2$ & 8.4 \\
$2-4$ & 9.9 \\
$4-6$ & 11.6 \\
$6-8$ & 13.6 \\
$8-10$ & 16.0 \\
$10-12$ & 18.9 \\
\hline
\end{tabular}

AOX1 promoter derepression in MFP (Tyagi et al., 2016). For this purpose, the same medium and conditions as in the batch runs were used including the same carbon-to-nitrogen ratio ensured by the selected feed solution.

Figure 3 illustrates the profiles of cell and glycerol concentrations in the medium throughout the fed-batch fermentation using the above described constant or pseudoexponential pattern for a $12 \mathrm{~h}$ period. The GFP phase started after glycerol depletion $(20 \mathrm{~h})$ with both feeding strategies. During GFP, the values of specific growth rate $\left(0.069 \mathrm{~h}^{-1}\right.$ for the constant flow rate and $0.085 \mathrm{~h}^{-1}$ for the pseudo-exponential one) were substantially lower than that in the batch phase $(0.219$ $\mathrm{h}^{-1}$ ) just because glycerol was fed at growth-limiting level.

Cell concentration achieved $27.7 \mathrm{~g}_{\mathrm{dcw}} \cdot \mathrm{L}^{-1}$ at the start of constant feed and $65.8 \mathrm{~g}_{\mathrm{dcw}} \cdot \mathrm{L}^{-1}$ at the end of the $12 \mathrm{~h}$ period. On the other hand, the pseudo-exponential feed started after the batch period when cell density was $24.7 \mathrm{~g}_{\mathrm{dcw}} \cdot \mathrm{L}^{-1}$ and stopped after $12 \mathrm{~h}$, reaching about the same cell concentration (68.3 $\mathrm{g}_{\mathrm{dcw}} \cdot \mathrm{L}^{-1}$ ) as the constant feed. At the end of fermentations, ethanol level was very low $\left(<0.2\right.$ gethanol. $\left.\mathrm{L}^{-1}\right)$ and similar for the two feeding patterns.

\section{ASNase Production in Bioreactor}

The objective of this part of the work was to induce ASNase II production by recombinant $P$. pastoris using methanol as the sole carbon source at high cell density. To ensure glycerol and ethanol depletion, the culture was submitted to a 1-2 h starvation period between GFP and induction phase. The same agitation speed and aeration rate as in the other phases (700 rpm and $1.0 \mathrm{vvm}$ ) were adopted, feeding pure methanol plus $12 \mathrm{mLPTM} \cdot \mathrm{L}_{\text {methanol }}^{-1}$. Since our previous work demonstrated no significant difference in growth at $\mathrm{pH} 5.0$ or 6.0 (results not shown), the latter value was selected to preserve the stability of produced enzyme. The culture was induced by means of methanol pulses (30 $\mathrm{mL}_{\text {methanol }} \cdot \mathrm{L}_{\text {initial medium }}^{-1}$ ) controlled by dissolved oxygen spikes (Stratton et al., 1998), which were performed after sudden dissolved oxygen increases.

The profiles of cell growth, periplasmic specific ASNase II activity, and glycerol concentration in the medium during fermentation are illustrated in Figure 4. GBP started with an initial glycerol concentration of 40 g.L $\mathrm{L}^{-1}$ and lasted $20 \mathrm{~h}$, GFP was performed with exponential feed rate for $12 \mathrm{~h}$, and, after the
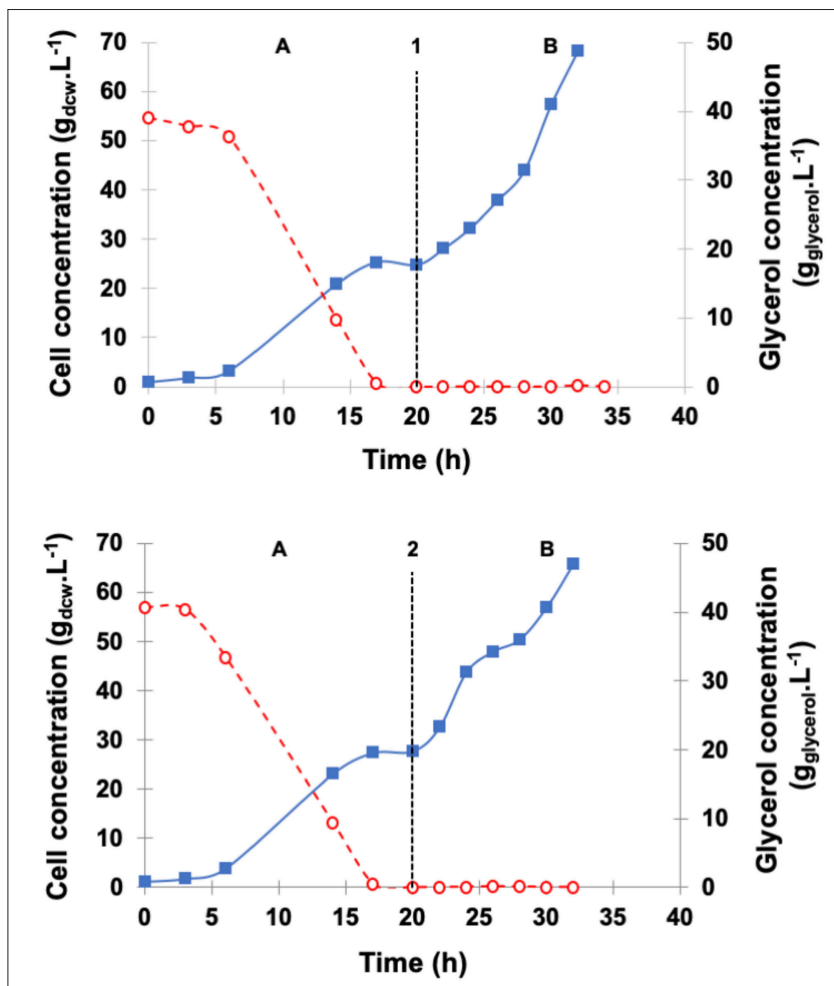

FIGURE 3 | Dry cell concentration of $P$. pastoris $(\square)$ and glycerol concentration (O) during high cell density cultures in bioreactor on BSMm. Conditions: temperature $30^{\circ} \mathrm{C}$, inoculum concentration $0.82 \mathrm{~g} \cdot \mathrm{L}^{-1}, \mathrm{pH} 5.0$, aeration 1.0 vvm, agitation $700 \mathrm{rpm}\left(k_{\mathrm{L}} \mathrm{a}=160 \mathrm{~h}^{-1}\right)$, and initial volume $1.5 \mathrm{~L}$. (A) Glycerol batch phase with $40 \mathrm{~g} \cdot \mathrm{L}^{-1}$ glycerol for $20 \mathrm{~h}$; (B) Glycerol fed-batch phase with

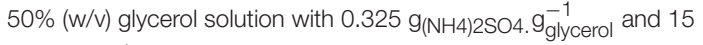

$\mathrm{mL}$ PTM $\cdot \mathrm{L}_{\text {glycerol solution }}^{-1}$ for $12 \mathrm{~h}$. (B1) Glycerol fed-batch phase with pseudo-exponential feeding (average flow rate $13 \mathrm{~mL} \cdot \mathrm{h}^{-1}$ ), and (B2) Glycerol fed-batch phase at constant feed $\left(13 \mathrm{~mL} \cdot \mathrm{h}^{-1}\right)$.

starvation period, glycerol and ethanol were totally consumed, while cell concentration reached $70 \mathrm{~g}_{\mathrm{dcw}} \cdot \mathrm{L}^{-1}$.

After $34 \mathrm{~h}$ of fermentation, i.e., at the end of glycerol starvation period, the culture was induced for $34 \mathrm{~h}$. The growth rate was low during the induction phase, at the end ASNase II specific activity (25.4 U. $\mathrm{g}_{\mathrm{dcw}}^{-1}$ ) was more than twice that detected in shaker, and cell concentration was as high as $82.5 \mathrm{gdcw}_{\mathrm{dcw}} \cdot \mathrm{L}^{-1}$.

\section{ASNase Induction by Methanol Pulses}

The use of methanol pulses was reported to be a simple and effective strategy to produce recombinant proteins (Dietzsch et al., 2011). Therefore, it has been adopted in the production step performed at $20^{\circ} \mathrm{C}$ and $\mathrm{pH} 6.0$, while keeping all the other growth conditions unvaried including constant flow rate $\left(13.1 \mathrm{~mL} . \mathrm{L}^{-1}\right)$ in GFP.

The profiles of cell, glycerol, and methanol concentrations as well as periplasmic specific ASNase II activity are illustrated in Figure 5. GFP started after glycerol depletion $(20 \mathrm{~h})$ when cell concentration was $27.0 \mathrm{gdcw} . \mathrm{L}^{-1}$. After the starvation period (1 h), glycerol and ethanol were absent, and cell concentration reached $61.0 \mathrm{gdcw}_{\mathrm{dcw}} \cdot \mathrm{L}^{-1}$ before the induction phase. 


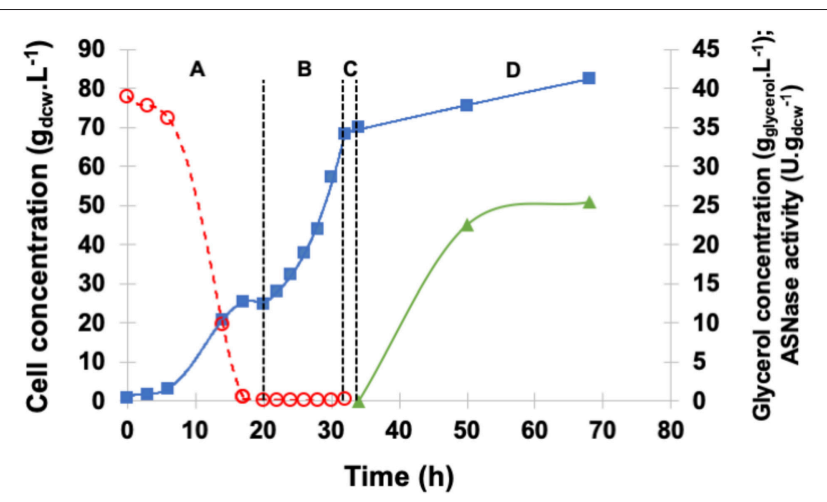

FIGURE 4 | Kinetic profile of ASNase I| production $(\mathbf{A})$ by recombinant $P$. pastoris in high cell density culture in bioreactor on BSMm under fed-batch methanol induction by pulses. Cell $(\square$ and glycerol (O) concentrations. (A) Glycerol batch phase with $40 \mathrm{~g} . \mathrm{L}^{-1}$ glycerol level for $20 \mathrm{~h}$; (B) Glycerol fed-batch phase at constant feed $\left(13 \mathrm{~mL} . \mathrm{h}^{-1}\right)$ with $50 \%(\mathrm{~W} / \mathrm{V})$ glycerol solution with $0.325 \mathrm{~g}(\mathrm{NH} 4) 2 \mathrm{SO} 4 . \mathrm{g}_{\text {glycerol }}^{-1}$ and $15 \mathrm{~mL}$ PTM $\cdot \mathrm{L}_{\text {glycerol solution }}^{-1}$ for $12 \mathrm{~h}$; (C) Starvation period of $2 \mathrm{~h}$. Conditions: temperature $30^{\circ} \mathrm{C}$, inoculum concentration $0.82 \mathrm{~g} . \mathrm{L}^{-1}, \mathrm{pH} 5.0$, aeration $1.0 \mathrm{vvm}$, agitation $700 \mathrm{rpm}\left(k_{\mathrm{L}} \mathrm{a}=\right.$ $160 \mathrm{~h}^{-1}$ ) and initial volume $1.5 \mathrm{~L}$. (D) Induction fed-batch phase at $20^{\circ} \mathrm{C}, \mathrm{pH}$ 6.0, with $100 \%$ methanol solution plus $12 \mathrm{mLPTM} \cdot \mathrm{L}_{\text {methanol }}^{-1}$ fed by two pulses (30 $\mathrm{mL} . \mathrm{L}^{-1}$ ) controlled by dissolved oxygen spikes.

At the end of induction, specific ASNase II activity reached 24.1 U.g $\mathrm{g}_{\mathrm{dcw}}^{-1}$ and cell concentration $90.1 \mathrm{gdcw} \cdot \mathrm{L}^{-1}$. After the first methanol pulse, a 2-h adaptation period was observed during which methanol was not consumed. Multiple pulses led to significant variations of $\mu$ that ranged from only 0.006 $\mathrm{h}^{-1}$ in the first pulse to $0.039 \mathrm{~h}^{-1}$ in the last one, with an average value throughout the whole induction phase of 0.033 $\mathrm{h}^{-1}$. After every methanol pulses, dry biomass concentration slightly decreased, and dissolved oxygen level dropped to $<10 \%$, confirming methanol toxicity and the high oxygen requirement of methanol metabolism (Bushell et al., 2003). Nonetheless, ASNase II levels were higher than in shake flasks and close to those detected with only two methanol pulses $\left(30 \mathrm{~mL} . \mathrm{L}^{-1}\right)$, which confirms the important role of oxygen in proteins induction and of high cell density in gene expression (Zhang et al., 2000b; Dietzsch et al., 2011). Ferrara et al. (2006) reported for ASNase II production in shake flasks glycerol depletion after $22-24 \mathrm{~h}, \mu$ of $0.30 \mathrm{~h}^{-1}$ and $\mathrm{Y}_{\mathrm{x} / \mathrm{s}}$ of $0.56 \mathrm{~g}^{\mathrm{g}} \mathrm{g}_{\text {glycerol }}^{-1}$. During cell growth, $\mathrm{pH}$ decreased from 6.0 to 2.9 , and before induction by methanol addition it was adjusted to 6.0 with $1 \mathrm{M} \mathrm{KOH}$. During the induction phase, a low cell growth rate and a gradual decrease of $\mathrm{pH}$ were observed. ASNase II levels were very high after $3 \mathrm{~h}$ of induction ( $394 \mathrm{U} \cdot \mathrm{g}_{\mathrm{dcw}}^{-1}$ ), reaching $562 \mathrm{U} \cdot \mathrm{g}_{\mathrm{dcw}}^{-1}$ in $5 \mathrm{~h}$. Finally, using methanol pulses, a maximum specific growth rate of 0.013 $\mathrm{h}^{-1}$ was obtained under the tested conditions, with no methanol limiting concentrations.

To evaluate ASNase II presence in the extracellular medium, SDS-PAGE of supernatant samples taken at the end of each pulse was performed. A band around $45 \mathrm{kDa}$ was detected in all samples collected after the induction (red arrow in Figure 6). This value is only a little higher than the molecular weight $(38.7 \mathrm{kDa})$ reported for $S$. cerevisiae ASNase II, a tetramer formed by four identical subunits each containing 362 amino

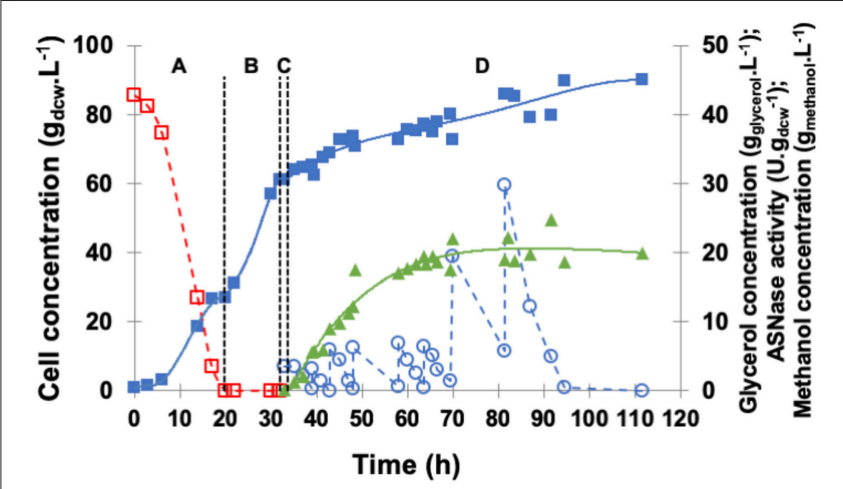

FIGURE $\mathbf{5}$ | Kinetic profile of ASNase II production $(\mathbf{A})$ by recombinant $P$. pastoris in high cell density culture in bioreactor on BSMm under fed-batch methanol induction by pulses. Cell $(\square)$ and glycerol ( $\square$ ) concentrations. (A) Glycerol batch phase with $40 \mathrm{~g} . \mathrm{L}^{-1}$ initial glycerol level for $20 \mathrm{~h}$; (B) Glycerol fed-batch phase at constant feed $\left(13 \mathrm{~mL} . \mathrm{h}^{-1}\right)$ with $50 \%(\mathrm{~W} / \mathrm{v})$ glycerol solution with $0.325 \mathrm{~g}(\mathrm{NH} 4) 2 \mathrm{SO} 4 . \mathrm{g}_{\text {glycerol }}^{-1}$ and $15 \mathrm{mLPTM} \cdot \mathrm{L}_{\text {glycerol solution }}^{-1}$ for $12 \mathrm{~h}$; (C) Starvation period of $1 \mathrm{~h}$. Conditions: temperature $30^{\circ} \mathrm{C}$, inoculum concentration $0.91 \mathrm{~g} \cdot \mathrm{L}^{-1}, \mathrm{pH} 5.0$, aeration $1.0 \mathrm{vvm}$, agitation $700 \mathrm{rpm}\left(k_{\mathrm{L}} \mathrm{a}=\right.$ $160 \mathrm{~h}^{-1}$ ) and initial volume $1.5 \mathrm{~L}$. (D) Induction fed-batch phase at $20^{\circ} \mathrm{C}, \mathrm{pH}$ 6.0, with $100 \%$ methanol (o) solution plus $12 \mathrm{mLPTM} \cdot \mathrm{L}_{\text {methanol }}^{-1}$ fed by pulses: 2 small pulses ( $\left.5 \mathrm{~mL} \cdot \mathrm{L}^{-1}\right), 4$ medium pulses $\left(10 \mathrm{~mL} \cdot \mathrm{L}^{-1}\right)$, and 2 large pulses (30 $\mathrm{mL} . \mathrm{L}^{-1}$ ) controlled by dissolved oxygen spikes.

acid residues (Dunlop et al., 1978; Ferrara et al., 2010), likely due to protein glycosylation (Ferrara et al., 2006; de Castro Girão et al., 2016). In fact, despite the lack of the original Lasparaginase signal sequence, the bioproduct was expected to be secreted or to accumulate in the periplasm. It is noteworthy that, since the extracellular enzyme activity was null (despite its presence), only the activity of the periplasmic enzyme was considered in this study. This interesting effect may be related to what was observed by Ferrara et al. (2006), who studied the expression of ASNase II in S. cerevisiae. These authors reported that non-secretion of protein (ASNase II) may have been due to an interaction of $S$. cerevisiae cell wall with some unidentified domain of ASNase II. Therefore, in the present case, it is possible that the enzyme secreted to the extracellular environment by $P$. pastoris may have undergone some modification to an inactive form. Likewise, Martínez et al. (2014) and Menéndez et al. (2013), who investigated the expression of exo- $\beta$-fructosidase from Thermotoga maritima by $P$. pastoris, observed secretion of this biomolecule into both the periplasmic space and the extracellular environment. On the other hand, there are some cases where proteins expressed by $P$. pastoris could not be secreted and remained in the periplasmic space, as it occurred for levansucrase (Lubineau et al., 1998) and human fucosyltransferase (Trujillo et al., 2001). According to the literature (Cereghino and Cregg, 2000; Cereghino et al., 2002), the efficiency of secretion depends not only on factors that direct the heterologous protein to the culture medium, but also on the nature of the protein structure.

\section{ASNase Production Induced by Continuous Methanol Feeding}

Methanol concentration is a critical parameter in $P$. pastoris cultivation since it influences both growth and heterologous 


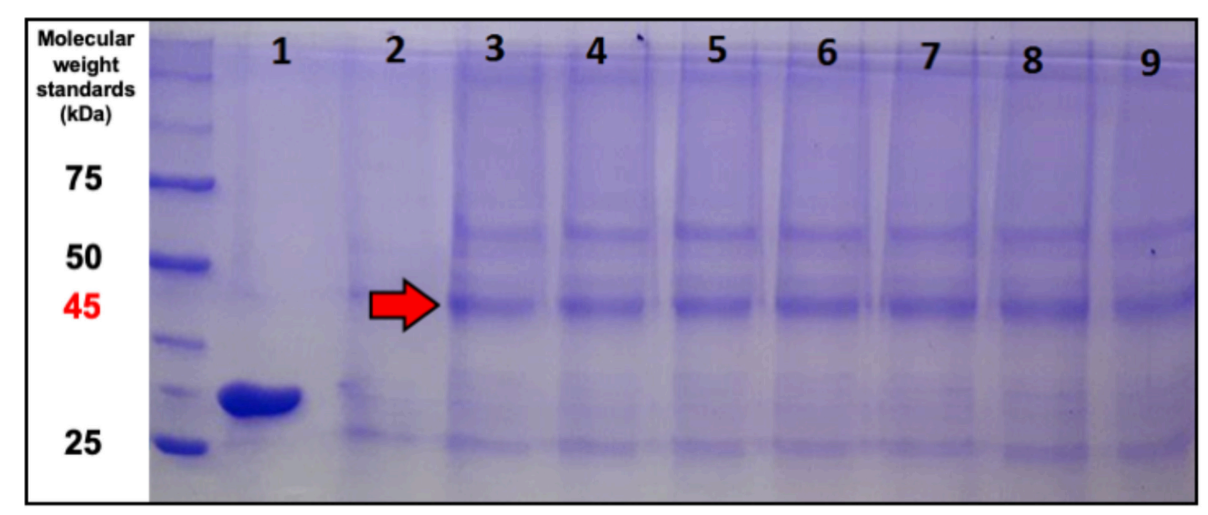

FIGURE 6 | SDS-PAGE of supernatant samples stained with Coomassie Blue. (1) Commercial E. coli ASNase taken as a control; (2) supernatant sample just before induction. Supernatant samples taken just after induction by: (3) $1^{\text {st }}$ pulse; (4) $2^{\text {nd }}$ pulse; (5) $3^{\text {rd }}$ pulse; (6) $4^{\text {th }}$ pulse; (7) $5^{\text {th }}$ pulse; (8) $6^{\text {th }}$ pulse; and (9) $8^{\text {th }}$ pulse.

gene expression under AOX promoter (Jahic et al., 2002; Cos et al., 2006). Some authors suggested to operate under conditions ensuring $\mu_{\max }$ in methanol induction phase (Looser et al., 2015), while others reported that they are not necessary for high expression levels. On the other hand, the dissolved oxygen level in the broth seems to be widely accepted as control parameter for methanol feeding.

Figure 7 shows the profiles of cell, glycerol, and methanol concentrations as well as periplasmic specific ASNase II activity in the medium under induction by continuous methanol feeding. GFP was started after glycerol depletion $(20 \mathrm{~h})$ when cell concentration achieved $28.6 \mathrm{gdcw}_{\mathrm{dc}} \cdot \mathrm{L}^{-1}$. After 1-h starvation and before induction, no glycerol or ethanol was detected, and biomass concentration reached $60.2 \mathrm{gdcw} \cdot \mathrm{L}^{-1}$. For continuous induction at $20^{\circ} \mathrm{C}$ and $\mathrm{pH} 6.0$, the feed rate was initially set at $2.6 \mathrm{~mL} \cdot \mathrm{h}^{-1}$ and then increased in such a way as to maintain dissolved oxygen level in the medium above $15 \%$ all the time (Zhang et al., 2000b; Bushell et al., 2003).

The average specific growth rate $\left(0.005 \mathrm{~h}^{-1}\right)$ under continuous methanol feeding was lower than that observed with pulses, cell concentration at the end of the 73-h induction period almost the same $\left(89.4 \mathrm{gdcw}_{\mathrm{d}} \cdot \mathrm{L}^{-1}\right)$, and specific ASNase II activity $\left(37.1 \mathrm{U} . \mathrm{g}_{\mathrm{dcw}}^{-1}\right) 55 \%$ higher. These results confirm that $\mu_{\max }$ is not necessarily an optimum condition for ASNase II production; oxygen availability seems, rather, to have played an important role in increasing ASNase II expression, by allowing cells to metabolize all methanol present in the medium avoiding the achievement of toxic levels (Tyagi et al., 2016). Moreover, continuous methanol feeding appeared to be the best strategy to ensure methanol-limited conditions, avoiding, at the same time, any oxygen limitation during MFP, and maximizing ASNase II expression.

Despite the lower specific ASNase II activity compared with P. pastoris carrying nitrogen de-repressed S. cerevisiae ure 2 dal80 $\left(106 \mathrm{U} \cdot \mathrm{g}_{\mathrm{dcw}}^{-1}\right)$, the ability of $P$. pastoris MUT strain used in this study to reach high cell density during fermentative growth allowed obtaining a volumetric activity $\left(3,315\right.$ U.L $\left.{ }^{-1}\right)$ more than one order of magnitude higher than that $\left(265\right.$ U.L $\left.{ }^{-1}\right)$ reported by Ferrara et al. (2004), and overall enzyme volumetric productivity of $31 \mathrm{U} \cdot \mathrm{L}^{-1} \cdot \mathrm{h}^{-1}$.

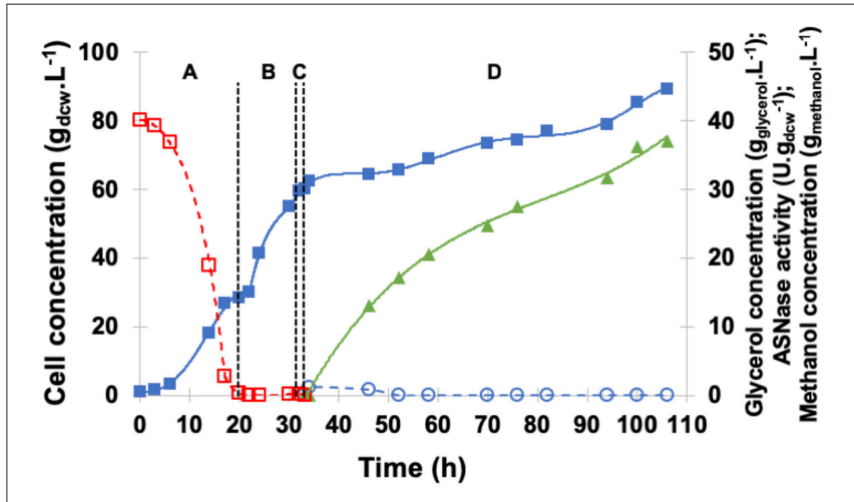

FIGURE 7 | Kinetic profile of ASNase I| production ( $\mathbf{\Delta}$ ) by recombinant $P$. pastoris in high cell density culture in bioreactor on BSMm under continuous methanol induction. Cell $(\square$ ) and glycerol $(\square)$ concentrations. (A) Glycerol batch phase with $40 \mathrm{~g} . \mathrm{L}^{-1}$ initial glycerol level for $20 \mathrm{~h}$. (B) Glycerol fed-batch phase at constant feed $\left(13 \mathrm{~mL} . \mathrm{h}^{-1}\right)$ with $50 \%(\mathrm{w} / \mathrm{v})$ glycerol solution with 0.325

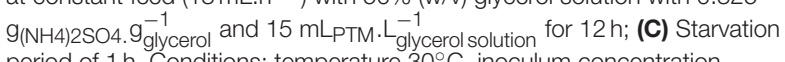
period of $1 \mathrm{~h}$. Conditions: temperature $30^{\circ} \mathrm{C}$, inoculum concentration $0.95 \mathrm{~g} \cdot \mathrm{L}^{-1}, \mathrm{pH} 5.0$, aeration $1.0 \mathrm{vvm}$, agitation $700 \mathrm{rpm}\left(\mathrm{k}_{\mathrm{L}} \mathrm{a}=160 \mathrm{~h}^{-1}\right)$ and initial volume $1.5 \mathrm{~L}$. (D) Induction fed-batch phase at $20^{\circ} \mathrm{C}, \mathrm{pH} 6.0$, with continuous feeding of $100 \%$ methanol (O) solution plus $12 \mathrm{mLPTM} \cdot \mathrm{L}_{\text {mehtanol }}^{-1}$

\section{CONCLUSIONS}

S. cerevisiae L-asparaginase II was produced by $P$. pastoris $M U T^{s}$ in multistage fed-batch cultivation divided in four distinct phases, namely glycerol batch, glycerol fed-batch, starvation, and methanol inducing phases. The main fermentation parameters determined in these phases were compared, namely specific growth rate, biomass yield, and enzyme activity. The recombinant $P$. pastoris strain used in this study showed optimum temperature for ASNase II production of $20^{\circ} \mathrm{C}$, using $3 \%(\mathrm{v} / \mathrm{v})$ methanol pulses every $24 \mathrm{~h}$ for a $48 \mathrm{~h}$ period in shake culture. In BSMm medium, biomass-to-glycerol yield was about $53 \%$ higher than in defined medium.

In glycerol batch fermentations under optimum $k_{\mathrm{L}} a$ conditions, the specific growth rate was $0.21 \mathrm{~h}^{-1}$ and biomass 
yield $0.77 \mathrm{~g} . \mathrm{g}_{\text {glycerol }}^{-1}$. Using these values for exponential growth, two feeding strategies, one based on an exponential feed profile and the other on a constant one, were adopted to ensure glycerol-limited conditions. Both were successful in achieving high cell densities (68.3 and $65.8 \mathrm{gdcw} \cdot \mathrm{L}^{-1}$, respectively), although biomass yields ( 0.55 and 0.51 g.g glycerol, respectively) were lower than in batch cultures. Using both glycerol feeding protocols ethanol concentration was negligible $\left(<0.2\right.$ g.L $\left.\mathrm{L}^{-1}\right)$. The adoption of a starvation period before methanol feeding avoided any $A O X$ repression due to the presence of ethanol or residual glycerol from glycerol fed-batch phase. The use of continuous methanol feeding for ASNase II induction allowed optimal control of methanol concentration in the medium, avoiding any oxygen limitation. Under these conditions, ASNase II was expressed at the highest levels. The results of this work demonstrate that not only methanol concentration but also oxygen availability in the induction phase are crucial for high recombinant protein production under the $A O X$ promoter regulation.

\section{AUTHOR CONTRIBUTIONS}

DR, OP-P, KT-O, JF-S, and IS-M performed bioreactor and flask fermentations and analysis in BMGY, BSMm, and SFMm media, acquired the data, performed data calculations, standardization

\section{REFERENCES}

Ahmad, M., Hirz, M., and Pichler, H. (2014). Protein expression in Pichia pastoris: recent achievements and perspectives for heterologous protein production. Appl. Microbiol. Biotechnol. 98, 5301-5317. doi: 10.1007/s00253-014-5732-5

Ali, U., Naveed, M., Ullah, A., Ali, K., Shah, S. A., Fahad, S., et al. (2016). L-asparaginase as a critical component to combat Acute Lymphoblastic Leukaemia (ALL): a novel approach to target ALL. Eur. J. Pharmacol. 771, 199-210. doi: 10.1016/j.ejphar.2015.12.023

Box, G. E. P., and Behnken, D. W. (1960). Some new three level design for the study of quantitative variables. Technometrics 2, 456-475. doi: 10.1080/00401706.1960.10489912

Brierley, R. A., Bussineau, C., Kosson, R., Melton, A., and Siegel, R. S. (1990). Fermentation development of recombinant Pichia pastoris expressing the heterologous gene: bovine lysozyme. Ann. New York Acad. Sci. 589, 350-362. doi: 10.1111/j.1749-6632.1990.tb24257.x

Bushell, M. E., Rowe, M., Avignone-Rossa, C. A., and Wardell, J. N. (2003). Cyclic fed-batch culture for production of human serum albumin in Pichia pastoris. Biotechnol. Bioeng. 82, 678-683. doi: 10.1002/bit.10616

Cereghino, G. P., Cereghino, J. L., Ilgen, C., and Gregg, J. M. (2002). Production of recombinant proteins in fermenter cultures of the yeast Pichia pastoris. Curr. Opin. Biotechnol. 13, 329-332. doi: 10.1016/S0958-1669(02)00330-0

Cereghino, J. L., and Cregg, J. M. (2000). Heterologous protein expression in the methylotrophic yeast Pichia pastoris. FEMS Microbiol. Rev. 24, 45-66. doi: 10.1111/j.1574-6976.2000.tb00532.x

Chiruvolu, V., Eskridge, K., Cregg, J., and Meagher, M. (1998). Effects of glycerol concentration and $\mathrm{pH}$ on growth of recombinant Pichia pastoris yeast. Appl. Biochem. Biotechnol. 75, 163-173. doi: 10.1007/BF02787771

Cos, O., Ramón, R., Montesinos, J. L., and Valero, F. (2006). Operational strategies, monitoring and control of heterologous protein production in the methylotrophic yeast Pichia pastoris under different promoters: a review. Microb. Cell Fact. 20, 1-20. doi: 10.1186/1475-2859-5-17

D'Anjou, M. C., and Daugulis, A. J. (2000). Mixed-feed exponential feeding for fed-batch culture of recombinant methylotrophic yeast. Biotechnol. Lett. 22, 341-346. doi: 10.1023/A:1005612415737 and assay of periplasmic specific ASNase II activity, interpreted the results and drafted the initial manuscript. MP and TB designed and constructed the recombinant $P$. pastoris system for ASNase expression. AC, AL, GM, LF, and AP conceived and designed the study, interpreted the results, and drafted the manuscript. All authors revised and approved the final manuscript.

\section{ACKNOWLEDGMENTS}

The authors are grateful for financial support from FAPESP (São Paulo Research Foundation, Brazil) through the following projects: \#2013/08617-7, and \#2017/10789-1. The authors also acknowledge the financial support from Conselho Nacional de Desenvolvimento Científico e Tecnológico (CNPq, projects \#445442/2014-0, and \#445442/2014-0) and Coordenação de Aperfeiçoamento de Pessoal de Nível Superior (CAPES). Gabriela O. Silveira is gratefully acknowledged for performing the ethanol and methanol analysis.

\section{SUPPLEMENTARY MATERIAL}

The Supplementary Material for this article can be found online at: https://www.frontiersin.org/articles/10.3389/fbioe. 2019.00016/full\#supplementary-material

de Castro Girão, L., Gonçalves da Rocha, S. L., Sobral, R. S., Dinis Ano Bom, A. P., Franco Sampaio, A. L., Godinho da Silva J. Jr., et al. (2016). Saccharomyces cerevisiae asparaginase II, a potential antileukemic drug: Purification and characterization of the enzyme expressed in Pichia pastoris. Protein Exp. Purif. 120, 118-125. doi: 10.1016/j.pep.2015.12.012

Dietzsch, C., Spadiut, O., and Herwig, C. (2011). A fast approach to determine a fed batch feeding profile for recombinant Pichia pastoris strains. Microb. Cell Fact. 10, 1-10. doi: 10.1186/1475-2859-10-85

Dunlop, P. C., Meyer, G. M., Ban, D., and Roon, R. J. (1978). Characterization of two forms of asparaginase in Saccharomyces cerevisiae. J. Biol. Chem. 253, 1297-1304.

Dunlop, P. C., Meyer, G. M., and Roon, R. J. (1980). Reactions of asparaginase II of Saccharomyces cerevisiae. A mechanistic analysis of hydrolysis and hydroxylaminolysis. J. Biol. Chem. 255, 1542-1546.

Dunlop, P. C., and Roon, R. J. (1975). L-Asparaginase of Saccharomyces cerevisiae: an extracellular enzyme. J. Bacteriol. 22, 1017-1024.

Ferrara, M. A., Mattoso, J. M., Bon, E. P., and Pereira, N. (2004). Kinetics of asparaginase II fermentation in Saccharomyces cerevisiae ure2dal80 mutant. Appl. Biochem. Biotech. 113, 299-305. doi: 10.1385/ABAB:113:1-3:299

Ferrara, M. A., Severino, N. M., Mansure, J. J., Martins, A. S., Oliveira, E. M., Siani, A. C., et al. (2006). Asparaginase production by a recombinant Pichia pastoris strain harbouring Saccharomyces cerevisiae ASP3 gene. Enzyme Microb. Technol. 39, 1457-1463. doi: 10.1016/j.enzmictec.2006.03.036

Ferrara, M. A., Severino, N. M. B., Valente, R. H., Perales, J., and Bon, E. P. (2010). High-yield extraction of periplasmic asparaginase produced by recombinant Pichia pastoris harbouring the Saccharomyces cerevisiae ASP3 gene. Enzyme Microb. Technol. 47, 71-76. doi: 10.1016/j.enzmictec.2010.05.001

Ghosalkar, A., Sahai, V., and Srivastava, A. (2008). Optimization of chemically defined medium for recombinant Pichia pastoris for biomass production. Bioresour. Technol. 99, 7906-7910. doi: 10.1016/j.biortech.2008.0 1.059

Hélène, B., Céline, L., Patrick, C., Fabien, R., Christine, V., Yves, C., et al. (2001). High-level secretory production of recombinant porcine folliclestimulating hormone by Pichia pastoris. Process Biochem. 36, 907-913. doi: 10.1016/S0032-9592(00)00296-X 
Itzel, A., Santos, P. D. L., Cayetano-Cruz, M., Gutiérrez-Antón, M., SantiagoHernández, A., Plascencia-Espinosa, M., et al. (2016). Improvement of catalytical properties of two invertases highly tolerant to sucrose after expression in Pichia pastoris. Effect of glycosylation on enzyme properties. Enzyme Microb. Technol. 83, 48-56. doi: 10.1016/j.enzmictec.2015.11.008

Jafari, R., Sundström, B. E., and Holm, P. (2011). Optimization of production of the anti-keratin 8 single-chain Fv TS1-218 in Pichia pastoris using design of experiments. Microb. Cell Fact. 10, 1-8. doi: 10.1186/1475-2859-10-34

Jahic, M., Martinelle, M., Hult, K., and Enfors, S. (2002). Modeling of growth and energy metabolism of Pichia pastoris producing a fusion protein. Bioproc. Biosyst. Eng. 24, 385-393. doi: 10.1007/s00449-001-0274-5

Jones, G. E. (1977). Genetic and physiological relationships between Lasparaginase I and asparaginase II in Saccharomyces cerevisiae. J. Bacteriol. 130, $128-130$.

Julien, C. (2006). Production of humanlike recombinant proteins in Pichia pastoris, from expression vector to fermentation strategy. Bioprocess Int. 2006, 22-31.

Kim, K. W., and Roon, R. J. (1983). Asparaginase II of Saccharomyces cerevisiae: comparison of enzyme stability in vivo and in vitro. Biochemistry. 22, 2704-2707. doi: 10.1021/bi00280a018

Körner, F. (2013). Evaluation of a Chemically Defined Medium for Pichia pastoris High Cell Density Fermentation Process. Hamburg University of Applied Sciences.

Li, X., He, X., Li, Z., and Wang, F. (2013). Combined strategies for improving the production of recombinant Rhizopus oryzae lipase in Pichia pastoris. BioResources 8, 2867-2880. doi: 10.15376/biores.8.2.2867-2880

Liu, C., Yang, W., Devidas, M., Cheng, C., Pei, D., Smith, C., et al. (2016). Clinical and genetic risk factors for acute pancreatitis in patients with acute lymphoblastic leukemia. J. Clin. Oncol. 34, 2133-2140. doi: 10.1200/JCO.2015.64.5812

Looser, V., Bruhlmann, B., Bumbak, F., Stenger, C., Costa, M., Camattari, A., et al. (2015). Cultivation strategies to enhance productivity of Pichia pastoris: a review. Biotechnol. Adv. 33, 1177-1193. doi: 10.1016/j.biotechadv.2015. 05.008

Lopes, A. M., Oliveira-Nascimento, L. D., Ribeiro, A., Tairum C. A. Jr., Breyer, C. A., Oliveira, M. A., et al. (2017). Therapeutic L-Asparaginase: upstream, downstream and beyond. Crit. Rev. Biotechnol. 37, 82-99. doi: $10.3109 / 07388551.2015 .1120705$

Lubineau, A., Le Narvor, C., Augé, C., Gallet, P. F., Petit, J. M., and Julien, R. (1998). Chemo-enzymatic synthesis of a selectin ligand using recombinant yeast cells. J. Mol. Catal. B-Enzym. 5, 229-234. doi: 10.1016/S1381-1177(98) 00041-1

Luo, D. (2012). Optimization of total polysaccharide extraction from Dioscorea nipponica Makino using response surface methodology and uniform design. Carbohyd. Polym. 90, 284-288. doi: 10.1016/j.carbpol.2012.05.036

Mandenius, C. F., and Brundin, A. (2008), Bioprocess optimization using design-of-experiments methodology. Biotechnol. Prog. 24, 1191-1203. doi: $10.1002 /$ btpr.67

Martínez, D., Cutiño-Avila, B., Pérez, E. R., Menéndez, C., Hernández, L., and del Monte-Martínez, A. (2014). A thermostable exo- $\beta$-fructosidase immobilised through rational design. Food Chem. 145, 826-831. doi: 10.1016/j.foodchem.2013.08.073

Meagher, M. M., and Inan, M. (2001). Non-repressing carbon sources for alcohol oxidase (AOX1) promoter of Pichia pastoris. J. Biosci. Bioeng. 92, 585-589. doi: 10.1016/S1389-1723(01)80321-2

Menéndez, C., Martínez, D., Trujillo, L. E., Mazola, Y., González, E., Pérez, E. R., et al. (2013). Constitutive high-level expression of a codon-optimized $\beta$ fructosidase gene from the hyperthermophile Thermotoga maritima in Pichia pastoris. Appl. Microbiol. Bio. 97, 1201-1212. doi: 10.1007/s00253-012-4270-2

Narta, U. K., Kanwar, S. S., and Azmi, W. (2007). Pharmacological and clinical evaluation of L-asparaginase in the treatment of leukemia. Crit. Rev. OncolHem. 61, 208-221. doi: 10.1016/j.critrevonc.2006.07.009

Panosyan, E. H., Seibel, N. L., Martin-Aragon, S., Gaynon, P. S., Avramis, I. A., Sather, H., et al. (2004). Asparaginase antibody and asparaginase activity in children with higher-risk acute lymphoblastic leukemia: Children's
Cancer Group study CCG-1961. J. Pedriat Hematol Oncol. 26, 217-226. doi: 10.1097/00043426-200404000-00002

Pichia Fermentation Process Guidelines (2002). Available online at: http://tools. lifetechnologies.com/content/sfs/manuals/pichiafermprot.pdf

Sabo, S. S., Converti, A., Ichiwaki, S., and Oliveira, R. P. S. (2019). Bacteriocin production by Lactobacillus plantarum ST16Pa in supplemented whey powder formulations. J. Dairy Sci. 102, 1-13. doi: 10.3168/jds.2018-14881

Santos, J., Sousa, M. J., and Leão, C. (2012). Ammonium is toxic for aging yeast cells, inducing death and shortening of the chronological lifespan. PLOS ONE 7:e37090. doi: 10.1371/journal.pone.0037090

Santos, J. H. P. M., Costa, I. M., Molino, J. V. D., Leite, M. S. M., Pimenta, M. V., Coutinho, J. A. P., et al. (2017). Heterologous expression and purification of active L-Asparaginase I of Saccharomyces cerevisiae in Escherichia coli host. Biotechnol. Prog. 33, 416-424. doi: 10.1002/btpr.2410

Stratton, J., Chiruvolu, V., and Meagher, M. (1998). "High cell-density fermentation," in Pichia Protocol, eds D. R. Higgins, and J. M. Cregg (Totowa, NJ: Humana Press), 107-120.

Sudhir, A. P., Dave, B. R., Prajapati, A. S., Panchal, K., Patel, D., and Subramanian, R. B. (2014). Characterization of a recombinant glutaminasefree L-Asparaginase (ansa3) enzyme with high catalytic activity from Bacillus licheniformis. Appl. Biochem. Biotechnol. 174, 2504-2515. doi: 10.1007/s12010-014-1200-z

Sun, W., Lai, Y., Li, H., Nie, T., Kuang, Y., Tang, X., et al. (2016). High level expression and purification of active recombinant human interleukin-15 in Pichia pastoris. J. Immunol. Methods 428, 50-57. doi: 10.1016/j.jim.2015.1 2.002

Trujillo, L. E., Arrieta, J. G., Dafhnis, F., García. J., Valdés, J., Tambara, Y., et al. (2001). Fructo-oligosaccharides production by the Gluconacetobacter diazotrophicus levansucrase expressed in the methylotrophic yeast Pichia pastoris. Enzyme Microb. Tech. 28, 139-144. doi: 10.1016/S0141-0229(00)00290-8

Tyagi, A., Kumar, A., Yadav, A. K., Saklani, A. C., Grover, S., and Batish, V. K. (2016). Functional expression of recombinant goat chymosin in Pichia pastoris bioreactor cultures: a commercially viable alternate. $L W T$ - Food Sci. Technol. 69, 217-224. doi: 10.1016/j.lwt.2016.01.015

Wang, Z. J., Luo, D. H., and Cai, E. N. (2007). Optimization of polysaccharides extraction from Gynostemma pentaphyllum Makino using uniform design. Carbohyd. Polym. 69, 311-317. doi: 10.1016/j.carbpol.2006.10.013

Wise, W. S. (1951). The measurement of the aeration of culture media. J. Gen. Microbiol. 5, 167-177. doi: 10.1099/00221287-5-1-167

Zhang, W., Bevins, M. A., Plantz, B. A., Smith, L. A., and Meagher, M. M. (2000b). Modeling Pichia pastoris growth on methanol and optimizing the production of a recombinant protein, the heavy-chain fragment $\mathrm{C}$ of botulinum neurotoxin, serotype A. Biotechnol. Bioeng. 70, 1-8. doi: 10.1002/ 1097-0290(20001005)70:1<1::AID-BIT1>3.0.CO;2-Y

Zhang, W., Meagher, M. M., and Inan, M. (2000a). Fermentation strategies for recombinant protein expression in the methylotrophic yeast Pichia pastoris. Biotechnol. Bioprocess Eng. 5, 275-287. doi: 10.1007/BF02942184

Zhang, W., Sinha, J., and Meagher, M. M. (2006). Glycerophosphate as a phosphorus source in a defined medium for Pichia pastoris fermentation. Appl. Microbiol. Biotechnol. 72, 139-144. doi: 10.1007/s00253-005-0238-9

Conflict of Interest Statement: The authors declare that the research was conducted in the absence of any commercial or financial relationships that could be construed as a potential conflict of interest.

Copyright (๑) 2019 Rodrigues, Pillaca-Pullo, Torres-Obreque, Flores-Santos, SánchezMoguel, Pimenta, Basi, Converti, Lopes, Monteiro, Fonseca and Pessoa. This is an open-access article distributed under the terms of the Creative Commons Attribution License (CC BY). The use, distribution or reproduction in other forums is permitted, provided the original author(s) and the copyright owner(s) are credited and that the original publication in this journal is cited, in accordance with accepted academic practice. No use, distribution or reproduction is permitted which does not comply with these terms. 